\title{
Neoechinulin A Imparts Resistance to Acute Nitrosative Stress in PC12 Cells: A Potential Link of an Elevated Cellular Reserve Capacity for Pyridine Nucleotide Redox Turnover with Cytoprotection
}

\author{
Soichiro Akashi, ${ }^{a}$ Kyo Shirai, ${ }^{a}$ Tatsumi Okada ${ }^{a, 1)}$ Kanako Konishi,${ }^{a}$ Toshifumi Takeuchi,${ }^{a \dagger}$ \\ Kouji Kuramochi, ${ }^{b}$ Muneaki Takahashi, ${ }^{a}$ Tomoya Nakagawa, ${ }^{a}$ Yuki Ogura, ${ }^{a}$ Satoshi Fujieda, ${ }^{a}$ \\ Yasushi Shibata, ${ }^{a}$ Fumio Sugawara, ${ }^{a}$ Susumu Kobayashi, ${ }^{c}$ Nobuo Watanabe, ${ }^{* a}$ and Takao Arai ${ }^{a}$ \\ ${ }^{a}$ Department of Applied Biological Science, Faculty of Science and Technology, Tokyo University of Science; \\ ${ }^{c}$ Department of Pharmaceutical Sciences, Tokyo University of Science; 2641 Yamazaki, Noda, Chiba 278-8510, \\ Japan: and ${ }^{b}$ Graduate School of Life and Environmental Sciences, Kyoto Prefectural University; 1-5 Shimogamo \\ Hangi-cho, Sakyo-ku, Kyoto 606-8522, Japan. Received January 16, 2012; accepted April 3, 2012
}

Treatment of PC12 cells with fungus-derived alkaloid neoechinulin A for more than $12 \mathrm{~h}$ renders the cells resistant to subsequent superoxide $\left(\mathrm{O}_{2}^{-}\right)$/nitric oxide (NO) insults derived from 3-morpholinosydnonimine (SIN-1). However, the underlying mechanism(s) remains largely unclear. To elucidate the mechanism(s), we assessed the specificity of the cytoprotection afforded by neoechinulin A treatment using other cytocidal stressors and also clarified the resulting cellular alterations, focusing on the antioxidant and metabolic enzymes systems. Neoechinulin A treatment for more than $12 \mathrm{~h}$ endowed PC12 cells with significant resistance to transient NO toxicity, but not persistent NO toxicity, bolus $\mathrm{H}_{2} \mathrm{O}_{2}$ toxicity, or oxidative insult from the redox cycling quinone menadione. Cellular antioxidant system profiling revealed no substantial potentiation of the activity of any antioxidant enzyme in lysate from the neoechinulin A-treated cells excluding glutathione (GSH) content, which was significantly decreased $(>50 \%)$, resulting in a proportional compromise in the thiol-reducing activity of the intact cells. In addition, no differences were observed in the activity for any nicotinamide adenine dinucleotide (phosphate) reduced form $(\mathrm{NAD}(\mathrm{P}) \mathrm{H})$-generating enzyme, steady-state NAD(P)H/nicotinamide adenine dinucleotide (phosphate) oxidized form $\left(\mathrm{NAD}(\mathrm{P})^{+}\right)$ratios, or the levels of total NAD(P)H. Nevertheless, the neoechinulin A-treated intact cells exhibited increased NAD(P)H redox turnover when driven by extracellular tetrazolium. The structurally inactive analog preechinulin failed to protect cells against NO toxicity or induce these alterations, suggesting their link with the cytoprotective mechanism. These results suggest that neochinulin A, despite disabling the GSH defense system, confers cytoprotection against nitrosative stresses by elevating the cellular reserve capacity for NAD(P)H generation, which could offset crippling of energy-supplying systems due to nitrosative stress.

Key words neurodegeneration; nitrosative stress; reserve capacity; glutathione; 2-(2-methoxy-4-nitrophenyl)3-(4-nitrophenyl)-5-(2,4-disulfophenyl)- $2 H$ tetrazolium

Neoechinulin A is an indole alkaloid consisting of indole, diketopiperazine, and isoprenyl moieties (Fig. 1). It has been isolated from various fungi and bacteria ${ }^{2)}$ (see references therein). Neoechinulin A has been reported to have antiproliferative activity toward various tumor cell lines ${ }^{3)}$ and proinflammatory activity in the lungs ${ }^{4}$; however, the biological activities of this alkaloid have not been fully investigated.

Excessive production of reactive oxygen species (ROS) and reactive nitrogen species (RNS) is associated with the pathogenesis of a range of neurodegenerative diseases including Alzheimer and Parkinson diseases. ${ }^{5,6)}$ Therefore, compounds that can ameliorate neuronal dysfunction resulting from oxidative/ nitrosative stresses have potential as therapeutics for these diseases. Previously, we found that the treatment of differentiated PC12 cells with neoechinulin A can render the cells resistant to oxidative/nitrosative stress derived from the superoxide $\left(\mathrm{O}_{2}{ }^{-}\right)$and nitric oxide (NO) cogenerator 3-morpholinosydnonimine (SIN-1). ${ }^{2,7,8)}$ Subsequent studies also demonstrated that neoechinulin A can also impede the progression of $\mathrm{PC} 12$ cell death induced by 1-methyl-4-phenylpyridinium $\left(\mathrm{MPP}^{+}\right)^{9)}$ and rotenone, ${ }^{10)}$ both of which are well-established Parkinson

The authors declare no conflict of interest.

${ }^{\dagger}$ Present address: Department of Chemistry, The University of Chicago, 5735 S Ellis Ave, Chicago, IL 60637, U.S.A. disease-inducing neurotoxins. However, the cytoprotective mechanisms against SIN-1 and neurotoxins are probably different. Cytoprotection against SIN-1 requires a minimum of $12 \mathrm{~h}$ of pretreatment before SIN-1 challenge, ${ }^{2)}$ suggesting the involvement of the induction of cytoprotective genes, such as antioxidant enzymes, in the mechanism. By contrast, for cytoprotection against $\mathrm{MPP}^{+}$or rotenone, the co-presence of<smiles>C=CC(C)(C)c1[nH]c2ccccc2c1/C=C1\NC(=O)[C@H](C)NC1=O</smiles><smiles>C=CC(C)(C)c1[nH]c2ccccc2c1C[C@@H]1NC(=O)[C@H](C)NC1=O</smiles>

Fig. 1. Structures of Neoechinulin A and Preechinulin (A) Neoechinulin A, (B) Preechinulin 
neoechinulin A during mitochondrial toxin exposure is indispensable, suggesting that a chemical property of the alkaloid, such as antioxidant activity, ${ }^{2,8)}$ may also play a role. ${ }^{9,10)}$

In pursuing the cytoprotective mechanisms of neoechinulin A, we have thus far revealed that the alkaloid itself has potent antioxidant activity against lipid peroxidation ${ }^{8)}$ and SIN-1-induced nitration of tyrosine residues in proteins. ${ }^{2,8}$ At the cellular level in intact cells, neoechinulin A treatment for a duration exceeding $12 \mathrm{~h}$ increases the ability of cells to reduce water-soluble tetrazolium (WST-8) under the catalysis of phenazine methosulfate, indicative of increased cellular nicotinamide adenine dinucleotide (phosphate) reduced form (NAD(P)H) production. ${ }^{2}$ Moreover, the double bond at $\mathrm{C} 8 / \mathrm{C} 9$ on the neoechinulin A molecule, which constitutes a conjugated system from the indole through diketopiperazine moieties, is a structural requirement for the cytoprotective actions and antioxidant activities of neoechinulin A. ${ }^{8,10)}$ Nevertheless, indepth molecular and cellular mechanisms for the cytoprotective action of neoechinulin A remain unknown.

To elucidate the mechanism, in this study, we investigated the specificity of cytoprotection imparted by neoechinulin A treatment for $24 \mathrm{~h}$ and potential cellular alterations associated with the treatment, focusing on key antioxidant and metabolic enzymes. We demonstrated herein that neoechinulin A preferentially affords cytoprotection against transient NO stress, but not persistent NO or oxidative stresses. Neoechinulin A treatment is associated with an elevation of the cellular reserve capacity for $\mathrm{NAD}(\mathrm{P}) \mathrm{H}$ recycling and, paradoxically, a decrease in cellular glutathione (GSH) content. Potential cytoprotective mechanisms are discussed in relation with these cellular alterations.

\section{MATERIALS AND METHODS}

Reagents Acetyl CoA, 1-chloro-2,4-dinitrobenzene (CDNB), cytochrome $c$, 5,5'-dithiobis(2-nitrobenzoic acid) (DTNB), Dulbecco's modified Eagle's medium (DMEM) (041-29775), glucose-6-phosphate (G6P), glutathione (GSH), iodoacetic acid, isocitrate, nitroblue tetrazolium (NBT), oxaloacetic acid, perchloric acid, RPMI 1640 medium (189-02025), and 5-sulfosalicylic acid were purchased from Wako Pure Chemicals (Osaka, Japan). Cell Counting Kit-8, $( \pm)$ - $(E)$-4-ethyl-2-[(E)-hydroxyimino]-5-nitro-3-hexenamide (NOR-3), and 3-morpholinosydnonimine (SIN-1) were purchased from Dojindo (Kumamoto, Japan). ATP, buthionine sulfoximine (BSO), catalase, dihydroethidium (DHE), 2-hydroxyethyl disulfide, menadione, phenazine ethosulfate, D-(-)-3-phosphoglyceric acid, 3-phosphoglyceric phosphokinase, triethanolamine, and xanthine were purchased from Sigma-Aldrich (St. Louis, MO, U.S.A.). Diethylenetriaminepentaacetic acid (DETAPAC), 3-[4,5-dimethylthiazol2-yl]-2,5-diphenyltetrazolium bromide (MTT), FAD, oxidized glutathione (GSSG), reduced and oxidized forms of nicotinamide adenine dinucleotide (NADH and $\mathrm{NAD}^{+}$), reduced and oxidized forms of nicotinamide adenine dinucleotide phosphate (NADPH and $\mathrm{NADP}^{+}$), and xanthine oxidase were purchased from Nacalai Tesque (Kyoto, Japan). Alcohol dehydrogenase, glucose-6-phosphate dehydrogenase (G6PDH), and glutathione reductase (GR) were purchased from Oriental Yeast (Tokyo, Japan). Sodium pyruvate were purchased from MP Biomedicals (Fountain Pkwy, OH, U.S.A.). Dicumarol, and 2,6-dichloroindophenol (DCPIP) were purchased from Tokyo Kasei (Tokyo, Japan). (Z)-1-[N-(2-Aminoethyl)- $N$-(2ammonioethyl)amino]diazen-1-ium-1,2-diolate (DETA-NONOate) was purchased from Cayman Chemical (Ann Arbor, MI, U.S.A.). $\quad N$-Acetyl-Arg-Leu-Arg-7-amido-4-methylcoumarin was purchased from Bachem Bioscience (King of Prussia, PA, U.S.A.). Other chemicals and salts were of analytical grade. Neoechinulin A and preechinulin were synthesized as described previously. ${ }^{7)}$

Cell Treatment and Viability Assay PC12 cells, a rat pheochromocytoma cell line, were routinely maintained in DMEM containing 5\% horse serum, $10 \%$ bovine calf serum, penicillin $\mathrm{G}(100 \mathrm{U} / \mathrm{mL})$, and streptomycin $(100 \mu \mathrm{g} / \mathrm{mL})$ in a humidified atmosphere of $5 \% \mathrm{CO}_{2}$ at $37^{\circ} \mathrm{C}$. Cell treatment and cytotoxicity assays were performed as described previously. ${ }^{8,10)}$ Briefly, PC12 cells were seeded into poly-L-lysinecoated 96-well plates at a density of 3000 cells/well and treated with nerve growth factor (NGF; $50 \mathrm{ng} / \mathrm{mL}$ ) for $4 \mathrm{~d}$ in RPMI 1640 medium containing 10\% FCS and antibiotics (RPMI/ FCS). The differentiated cells were subsequently incubated with neoechinulin A or its vehicle $(0.1 \%$ dimethyl sulfoxide (DMSO)) in RPMI/FCS for an additional $24 \mathrm{~h}$. Neoechinulin A treatment $(100 \mu \mathrm{mol} / \mathrm{L})$ for $24 \mathrm{~h}$ did not affect the cell number $(95 \pm 12 \%$ of control, $n=5)$.

For cytotoxicity assays, the control and neoechinulin Apretreated cells were exposed to various oxidative/nitrosative stressors in RPMI/FCS, typically for $24 \mathrm{~h}$, and cell viability was evaluated by lactate dehydrogenase (LDH) assay. ${ }^{10)}$ In some experiments, cell viability was also evaluated using MTT assay. After treatment with SIN-1 or NOR-3, cells were incubated with fresh medium containing MTT $(0.5 \mathrm{mg} / \mathrm{mL})$ for $2 \mathrm{~h}$. Formazan was dissolved in $150 \mu \mathrm{L}$ of DMSO, and absorbance at $570 \mathrm{~nm}$ was measured. NGF $(50 \mathrm{ng} / \mathrm{mL})$ was included in RPMI/FCS throughout the experiments.

Measurement of Cellular Antioxidant and Metabolic Enzyme Activities PC12 cells in 100-mm dishes were NGF-differentiated and incubated with either neoechinulin A $(100 \mu \mathrm{mol} / \mathrm{L})$ or its vehicle $(0.1 \%$ DMSO) for $24 \mathrm{~h}$ as described above. The cells were washed with phosphate buffered saline (PBS) and lyzed on ice with $0.5 \%$ Triton X-100 in PBS. The lysates were centrifuged at $10000 \times \mathrm{g}$ for $10 \mathrm{~min}$ at $4{ }^{\circ} \mathrm{C}$; the supernatants were collected, divided into aliquots, and stored at $-80^{\circ} \mathrm{C}$ until use. Unless otherwise specified, enzyme assays were performed at $25^{\circ} \mathrm{C}$ in 96 -well assay plates, and the reaction kinetics were measured using a SpectraMax 190 plate reader (Molecular Devices). Reactions were performed at $200 \mu \mathrm{L} /$ well, and the light path length at this volume was regarded as $0.5 \mathrm{~cm}$. Lysates were appropriately diluted in the lysis buffer before each assay.

Antioxidant (Enzymes) Assays Total superoxide dismutase (SOD) activity was evaluated by the cytochrome $c$ l xanthine/xanthine oxidase system. ${ }^{11)}$ Fifty microliters of lysates were mixed with $150 \mu \mathrm{L}$ of reaction mixture in PBS to give the following final concentration for each constituent: $10 \mu \mathrm{mol} / \mathrm{L}$ ferricytochrome $c, 11 \mathrm{mU} / \mathrm{mL}$ xanthine oxidase, $50 \mu \mathrm{mol} / \mathrm{L}$ xanthine, $10 \mu \mathrm{g} / \mathrm{mL}$ catalase, and $100 \mu \mathrm{mol} / \mathrm{L} \mathrm{DE}-$ TAPAC. Changes in absorbance at $550 \mathrm{~nm}$ were monitored, and one unit of activity was defined as the amount of enzyme required for $50 \%$ inhibition of the rate of ferricytochrome $c$ reduction. The activity was calculated using the following equation: 
activity $(\mathrm{U} / \mathrm{mL})=V_{\text {control }} / V_{\text {lysate }}-1$, where $V_{\text {control }}$ and $V_{\text {lysate }}$ are the rates of cytochrome $c$ reduction in the absence or presence of cell lysate, respectively.

GR activity was assayed by monitoring GSSG-dependent NADPH oxidation at $\left.340 \mathrm{~nm}\left(\varepsilon_{340}=6220 \mathrm{M}^{-1} \mathrm{~cm}^{-1}\right) .{ }^{12}\right)$ Lysates $(100 \mu \mathrm{L})$ were mixed with the reaction mixture in $0.1 \mathrm{M} \mathrm{NaP} i$ ( $\mathrm{pH}$ 7.4) to give the following final concentration for each constituent: $200 \mu \mathrm{mol} / \mathrm{L}$ NADPH, $200 \mu \mathrm{mol} / \mathrm{L}$ DETAPAC, and $2 \mathrm{mmol} / \mathrm{L}$ GSSG. One unit of activity was defined as $1 \mu \mathrm{mol} /$ min of NADPH oxidation.

Glutathione peroxidase (GPx) activity with $\mathrm{H}_{2} \mathrm{O}_{2}$ was determined by measuring GR-coupled NADPH oxidation at $340 \mathrm{~nm} .{ }^{13)}$ Lysates $(50 \mu \mathrm{L})$ were mixed with $100 \mu \mathrm{L}$ of $\mathrm{H}_{2} \mathrm{O}_{2}$ in PBS and $50 \mu \mathrm{L}$ of reaction constituents in $0.1 \mathrm{M} \mathrm{NaPi}$ ( $\mathrm{pH}$ 7.4). The final concentration of each constituent was as follows: $200 \mu \mathrm{mol} / \mathrm{L} \mathrm{H}_{2} \mathrm{O}_{2}, 200 \mu \mathrm{mol} / \mathrm{L} \mathrm{NADPH}, 5 \mathrm{mmol} / \mathrm{L} \mathrm{GSH}, 2 \mathrm{U} /$ $\mathrm{mL} \mathrm{GR}, 200 \mu \mathrm{mol} / \mathrm{L} \mathrm{NaN}_{3}$, and $200 \mu \mathrm{mol} / \mathrm{L}$ DETAPAC. GSHdependent NADPH oxidation was monitored as described for the GR assay. One unit was defined as $1 \mu \mathrm{mol} / \mathrm{min}$ of NADPH oxidation.

$\mathrm{NAD}(\mathrm{P}) \mathrm{H}$ quinone oxidoreductase (NQO) activity was measured by the dicoumarol-inhibitable reduction of DCPIP at $600 \mathrm{~nm}\left(\varepsilon_{600}=21000 \mathrm{M}^{-1} \mathrm{~cm}^{-1}\right) .{ }^{14)}$ Lysates $(100 \mu \mathrm{L})$ were mixed with $100 \mu \mathrm{L}$ of reaction constituents in $0.1 \mathrm{M} \mathrm{NaPi}$ (pH 7.4) to give the following final concentration for each constituent: $100 \mu \mathrm{mol} / \mathrm{L}$ DCPIP, $200 \mu \mathrm{mol} / \mathrm{L} \mathrm{NADPH}$, and $5 \mu \mathrm{mol} / \mathrm{L}$ FAD with or without $10 \mu \mathrm{mol} / \mathrm{L}$ dicoumarol. The dicoumarol-inhibitable DCPIP reduction rate was calculated, and one unit was defined as $1 \mu \mathrm{mol} / \mathrm{min}$ of DCPIP reduction.

Thioredoxin (Trx) reductase (TrxR)-like activity was evaluated by the NADPH-dependent reduction of DTNB. ${ }^{15)}$ Lysates $(100 \mu \mathrm{L})$ were mixed with $100 \mu \mathrm{L}$ of reaction constituents in $0.1 \mathrm{M} \mathrm{NaP} i$ ( $\mathrm{pH}$ 7.4). The final concentration of each constituent was as follows: $200 \mu \mathrm{mol} / \mathrm{L}$ NADPH, $1.25 \mathrm{mmol} / \mathrm{L}$ DTNB, and $1 \mathrm{mmol} / \mathrm{L}$ DETAPAC. The NADPH-dependent change in A412 was then converted into the rate of 5-Thiobenzoic acid (TNB) generation with an extinction coefficient of $412 \mathrm{~nm}$ $\left(\varepsilon_{412}\right)$ of $13600 \mathrm{M}^{-1} \mathrm{~cm}^{-1}$. One unit was defined as the generation of $2 \mu \mathrm{mol} / \mathrm{min} \mathrm{TNB}$ with the expense of $1 \mu \mathrm{mol} / \mathrm{min}$ NADPH.

Glutathione $S$-transferase (GST) activity was assessed using CDNB as a substrate. ${ }^{16)}$ Lysate $(50 \mu \mathrm{L})$ was mixed with $150 \mu \mathrm{L}$ of reaction constituents in $0.1 \mathrm{M} \mathrm{NaP} i$ to give the following final concentration for each constituent: $1 \mathrm{mmol} / \mathrm{L}$ CDNB, $2 \mathrm{mmol} / \mathrm{L}$ GSH, $0.2 \mathrm{~mm}$ DETAPAC, and $10 \%$ (v/v) ethanol. After subtracting the rate of non-enzymatic conjugation, the rate of net absorbance change was converted into the rate of CDNB-GSH formation by using an $\varepsilon_{340}$ of $9600 \mathrm{M}^{-1} \mathrm{~cm}^{-1}$. One unit of activity was defined as $1 \mu \mathrm{mol} / \mathrm{min}$ of CDNB-GS formation.

$S$-Nitrosoglutathione (GSNO) reductase (GSNOR) activity was measured by GSNO-dependent NADH oxidation using a combined $\varepsilon_{412}$ of $7060 \mathrm{M}^{-1} \mathrm{~cm}^{-1}$ for GSNO and NADH. ${ }^{17)}$ Lysates $(100 \mu \mathrm{L})$ were mixed with $100 \mu \mathrm{L}$ of reaction constituents in PBS to give the following final concentration for each constituent: $100 \mu \mathrm{mol} / \mathrm{L}$ GSNO, $200 \mu \mathrm{mol} / \mathrm{L}$ NADH, and $500 \mu \mathrm{mol} / \mathrm{L}$ DETAPAC. One unit of activity was defined as $1 \mu \mathrm{mol} / \mathrm{min}$ of NADH oxidation. GSNO was synthesized from acidified nitrite and GSH as described previously. ${ }^{18)}$

Total GSH content was measured by the GR-coupled recycling assay. ${ }^{19)}$ Proteins were precipitated from cell lysates via mixing with equal volumes of $10 \%$ (w/v) 5 -sulfosalicylic acid, followed by centrifugation. The acid-soluble supernatants were neutralized with $33 \%(\mathrm{v} / \mathrm{v})$ triethanolamine. Twenty microliters of sample were combined with reaction constituents in $0.1 \mathrm{M}$ $\mathrm{NaP} i$ ( $\mathrm{pH}$ 7.4) to give the following final concentration for each constituent: $200 \mu \mathrm{mol} / \mathrm{L}$ NADPH, $1 \mathrm{mmol} / \mathrm{L}$ DETAPAC, $1 \mathrm{U} / \mathrm{mL}$ GR, and $600 \mu \mathrm{mol} / \mathrm{L}$ DTNB. For the quantitation of GSH concentrations in culture medium, $75 \mu \mathrm{L}$ of media were mixed directly with $125 \mu \mathrm{L}$ of the same final concentrations of reaction constituents as above in $25 \mathrm{mmol} / \mathrm{L} \mathrm{NaPi}(\mathrm{pH}$ 7.4). The rates of the increase in A412 were measured and converted into GSH concentrations by using a standard curve calculated using authentic GSH.

Catalase activity was assayed on a spectrophotometer (U-3010; Hitachi, Japan). Lysates $(180 \mu \mathrm{L})$ were mixed in $720 \mu \mathrm{L}$ of $\mathrm{H}_{2} \mathrm{O}_{2}$ in PBS in cuvettes to give a final $\mathrm{H}_{2} \mathrm{O}_{2}$ concentration of $10 \mathrm{mmol} / \mathrm{L}$. The rate of $\mathrm{H}_{2} \mathrm{O}_{2}$ decomposition was calculated using an $\varepsilon_{240}$ of $39.4 \mathrm{M}^{-1} \mathrm{~cm}^{-1}$. ${ }^{20)}$ One unit of activity was defined as $1 \mu \mathrm{mol} / \mathrm{min}$ of $\mathrm{H}_{2} \mathrm{O}_{2}$ decomposition. The authenticity of the catalase activities detected in the cell lysates was confirmed by the almost complete inhibition with $0.1 \mathrm{mmol} / \mathrm{L} \mathrm{NaN}_{3}$.

Metabolic Enzyme Assays Hexokinase (HK) activity was measured by means of G6PDH-coupled NADPH generation. $^{21)}$ Lysate $(50 \mu \mathrm{L})$ was mixed with $150 \mu \mathrm{L}$ of reaction constituents in $50 \mathrm{mmol} / \mathrm{L}$ triethanolamine $/ \mathrm{HCl}$ buffer $(\mathrm{pH}$ 7.4) to give the following final concentration for each constituent: $1.25 \mathrm{mmol} / \mathrm{L}$ glucose, $5 \mathrm{mmol} / \mathrm{L}$ ATP, $4 \mathrm{mmol} / \mathrm{L} \mathrm{MgCl}_{2}$, $0.5 \mathrm{mmol} / \mathrm{L} \mathrm{NADP}{ }^{+}$, and $1 \mathrm{U} / \mathrm{mL}$ G6PDH. The rate of ATPdependent NADPH generation was monitored at $340 \mathrm{~nm}$, and one unit of activity was defined as $1 \mu \mathrm{mol} / \mathrm{min}$ of NADPH generation.

Glyceraldehyde 3-phosphate dehydrogenase (GAPDH) activity was assessed in the gluconeogenetic direction. ${ }^{22}$ Lysate $(50 \mu \mathrm{L})$ was mixed with $150 \mu \mathrm{L}$ of reaction constituents in $50 \mathrm{mmol} / \mathrm{L}$ triethanolamine/ $\mathrm{HCl}$ buffer $(\mathrm{pH} 7.4)$ to give the following final concentration for each constituent: $1 \mathrm{mmol} / \mathrm{L}$ 3-phosphoglyceric acid, $5 \mathrm{mmol} / \mathrm{L}$ ATP, $0.2 \mathrm{mmol} / \mathrm{L} \mathrm{NADH}$, $3 \mathrm{U} / \mathrm{mL}$ 3-phosphoglyceric phosphokinase, $1 \mathrm{mmol} / \mathrm{L}$ DETA$\mathrm{PAC}$, and $5 \mathrm{mmol} / \mathrm{L} \mathrm{MgCl}_{2}$. The rate of $\mathrm{NADH}$ oxidation in the steady-state phase was used for calculation using an $\varepsilon_{340}$ of $6220 \mathrm{M}^{-1} \mathrm{~cm}^{-1}$. One unit of activity was defined as $1 \mu \mathrm{mol} / \mathrm{min}$ of NADH oxidation.

Citrate synthase (CS) activity was measured by means of coupled DTNB reduction with CoA generated from the reaction of acetyl CoA and oxaloacetate. ${ }^{23)}$ Lysate $(50 \mu \mathrm{L})$ was mixed with reaction constituents in $150 \mu \mathrm{L}$ of $50 \mathrm{mmol} / \mathrm{L}$ Tris- $\mathrm{HCl}$ ( $\mathrm{pH}$ 7.4) to give the following final concentration for each constituent: $100 \mu \mathrm{mol} / \mathrm{L}$ acetyl CoA, $200 \mu \mathrm{mol} / \mathrm{L}$ DTNB, $500 \mu \mathrm{mol} / \mathrm{L}$ oxaloacetate, and $250 \mu \mathrm{mol} / \mathrm{L}$ DETAPAC. TNB release was monitored at $412 \mathrm{~nm}\left(\varepsilon_{412}=13600 \mathrm{M}^{-1} \mathrm{~cm}^{-1}\right)$, and one unit of activity was defined as $1 \mu \mathrm{mol} / \mathrm{min}$ of TNB generation.

The activities of G6PDH and 6-phosphogluconate dehydrogenase $(6 \mathrm{PGDH})$ were determined by the rates of NADPH generation at $340 \mathrm{~nm}^{24,25)}$ Lysate $(100 \mu \mathrm{L})$ was mixed with $100 \mu \mathrm{L}$ of reaction constituents in PBS to give the following final concentration for each constituent: $250 \mu \mathrm{mol} / \mathrm{L} \mathrm{NADP}^{+}$, $100 \mu \mathrm{mol} / \mathrm{L}$ DETAPAC, and $250 \mu \mathrm{mol} / \mathrm{L}$ G6P. G6PDH activity was calculated from the initial rate of NADPH generation. Due to the accumulation of 6-P-glucono- $\delta$-lactone, the reaction rate increased with time and became constant, where the 
level of 6-P-glucono- $\delta$-lactone reached a steady state. $6 \mathrm{PGDH}$ activity was calculated by subtracting the rate of maximum NADPH generation from G6PDH activity observed at the initial stage. One unit of activity was defined as $1 \mu \mathrm{mol} / \mathrm{min}$ of NADPH generation.

$\mathrm{NADP}^{+}$-isocitrate dehydrogenase (ICDH) activity was measured by the rate of isocitrate-dependent NADPH generation at $340 \mathrm{~nm}$ and $37^{\circ} \mathrm{C} .^{26)}$ Lysates $(100 \mu \mathrm{L})$ were mixed with $100 \mu \mathrm{L}$ of reaction constituents in PBS to give the following final concentration for each constituent: $500 \mu \mathrm{mol} / \mathrm{L} \mathrm{NADP}^{+}$, $200 \mu \mathrm{mol} / \mathrm{L}$ DETAPAC, $2 \mathrm{mmol} / \mathrm{L} \quad \mathrm{MgCl}_{2}$, and $2 \mathrm{mmol} / \mathrm{L}$ isocitrate. One unit of activity was defined as $1 \mu \mathrm{mol} / \mathrm{min}$ of NADPH generation.

NADH- and NADPH-linked diaphorase activities were evaluated using NBT as an electron accepter. Lysates $(100 \mu \mathrm{L})$ were mixed with $100 \mu \mathrm{L}$ of reaction constituents in $50 \mathrm{mmol} / \mathrm{L}$ Tris- $\mathrm{HCl}(\mathrm{pH}$ 7.4) to give the following final concentration for each constituent: $1 \mathrm{mmol} / \mathrm{L} \mathrm{NBT,} 2.5 \mathrm{mmol} / \mathrm{L}$ ethylenediamine tetraacetic acid (EDTA), and $200 \mu \mathrm{mol} / \mathrm{L} \mathrm{NADH}$ or NADPH. Lysate-dependent NBT reduction activity was expressed as the rate of the change of absorbance at $550 \mathrm{~nm}$ per $\mathrm{mg}$ of protein in the well (mAbs/mg).

Proteasome activity was measured using a fluorescent peptide substrate (Ac-Arg-Leu-Arg-7-amino-4-methycoumarin). Lysate $(100 \mu \mathrm{L})$ was mixed with $100 \mu \mathrm{L}$ of the substrate and DETAPAC in $0.1 \mathrm{~mol} / \mathrm{L} \mathrm{NaPi}(\mathrm{pH} 7.4)$ to give final concentrations of $10 \mu \mathrm{mol} / \mathrm{L}$ and $0.1 \mathrm{mmol} / \mathrm{L}$, respectively, and then incubated at $37^{\circ} \mathrm{C}$. 7-amino-4-methycoumarin fluorescence was measured using a fluorescence plate reader (Fluoro Count, Packard, Meriden, U.S.A.) with excitation and emission wavelengths of 380 and $460 \mathrm{~nm}$, respectively, and the activity was calculated from an 7-amino-4-methycoumarin standard curve. The addition of the proteasome inhibitor MG-132 (final concentration, $10 \mu \mathrm{mol} / \mathrm{L})$ completely inhibited the lysatedependent 7-amino-4-methycoumarin release, thus verifying the specificity (data not shown).

Determination of the Levels of NAD(P)H Cellular pyridine nucleotide levels were measured by the dehydrogenase-mediated pyridine nucleotide recycling-coupled MTT reduction assay. ${ }^{27)}$ Briefly, cells were lyzed in a lysis buffer $(0.5 \%$ Triton-X100, $20 \mathrm{mmol} / \mathrm{L}$ nicotinamide, $20 \mathrm{mmol} / \mathrm{L}$ $\mathrm{NaHCO}_{3}, 100 \mathrm{mmol} / \mathrm{L} \mathrm{Na}_{2} \mathrm{CO}_{3}$ ) and centrifuged at $10,000 \times$ $G$ for $10 \mathrm{~min}$ at $4^{\circ} \mathrm{C}$. DNA in the supernatant was removed by a $0.45-\mu \mathrm{m}$ filter, and the resulting extract was divided into two aliquots. One aliquot was heated at $60^{\circ} \mathrm{C}$ for $30 \mathrm{~min}$ to destroy oxidized forms of pyridine nucleotide, and the other aliquot was kept on ice to detect total pyridine nucleotides. Heat-treated and non-treated extracts were subjected to PEScatalyzed MTT reduction assays. To detect NADP(H), NADP ${ }^{+}$ was recycled by G6P and G6PDH. The final concentrations in $200 \mu \mathrm{L}$ were as follows: $0.4 \mathrm{mmol} / \mathrm{L} \mathrm{MTT}, 1.6 \mathrm{mmol} / \mathrm{L}$ phenazine ethosulfate, $0.2 \mathrm{mmol} / \mathrm{L}$ G6P, $1.6 \mathrm{U} / \mathrm{mL}$ G6PDH, $8 \mathrm{mg} / \mathrm{mL}$ bovine serum albumin (BSA), $0.8 \mathrm{mmol} / \mathrm{L}$ EDTA, and $80 \mathrm{mmol} / \mathrm{L}$ Tris- $\mathrm{HCl}(\mathrm{pH} 8.0)$. To detect NAD(H), NAD ${ }^{+}$ was recycled by ethanol and alcohol dehydrogenase. The final concentrations in $200 \mu \mathrm{L}$ were as follows: $0.4 \mathrm{mmol} / \mathrm{L} \mathrm{MTT}$, $0.8 \mathrm{mmol} / \mathrm{L}$ phenazine ethosulfate, $12 \mathrm{U} / \mathrm{mL}$ alcohol dehydrogenase, $0.6 \mathrm{mmol} / \mathrm{L}$ ethanol, and $8 \mathrm{mg} / \mathrm{mL} \mathrm{BSA}$ in $80 \mathrm{mmol} / \mathrm{L}$ Tris- $\mathrm{HCl}(\mathrm{pH}$ 8.0). The rate of change of A570 was monitored, and each pyridine nucleotide concentration was calculated from a standard curve made using the respective
$\mathrm{NAD}(\mathrm{P}) \mathrm{H}$ concentrations. The concentration of $\mathrm{NAD}(\mathrm{P})^{+}$was calculated by subtracting the concentration of NAD $(\mathrm{P}) \mathrm{H}$ (heatstable) from the respective concentration of total pyridine nucleotides $\left[\mathrm{NAD}(\mathrm{P}) \mathrm{H}+\mathrm{NAD}(\mathrm{P})^{+}\right]$. Supplementation of a known concentration of $\mathrm{NAD}(\mathrm{P}) \mathrm{H}$ or $\mathrm{NAD}(\mathrm{P})^{+}$into $\mathrm{PC} 12$ cell extract resulted in an additive increase in the levels of the respective pyridine nucleotide, confirming the specificity of the assays (data not shown).

Measurement of the Thioltransferase Activity of Cells Cellular thioltransferase activity was measured according to the procedure of Biaglow et al. $^{28)}$ with some modifications. Briefly, after treatment without or with neoechinulin A $(100 \mu \mathrm{mol} / \mathrm{L})$ for $24 \mathrm{~h}$ in 12 -well plates, the medium was removed, and the cells were washed with PBS. Cells were incubated with $500 \mu \mathrm{L}$ of $5 \mathrm{mmol} / \mathrm{L}$ 2-hydroxyethyl disulfide (HEDS) in PBS containing $10 \mathrm{mmol} / \mathrm{L}$ glucose, $1 \mathrm{mmol} / \mathrm{L}$ $\mathrm{MgCl}_{2}$, and $1 \mathrm{mmol} / \mathrm{L} \mathrm{CaCl}_{2}$ at $37^{\circ} \mathrm{C}$ for 15 or $30 \mathrm{~min}$. The media were collected, 2-mercaptoethanol in the media was detected with $200 \mu \mathrm{mol} / \mathrm{L}$ DTNB, and the absorbance was measured at $412 \mathrm{~nm}$. Reduced thiol content was calculated using GSH as a standard. The thioltransferase activity was normalized by the concentration of cell protein remaining in the well after the assay.

WST-8 Reduction Assay Cellular capacity to reduce extracellular tetrazolium was measured by using the Cell Counting Kit-8, which contains $5 \mathrm{mmol} / \mathrm{L}$ WST-8, $0.2 \mathrm{mmol} / \mathrm{L}$ 1-methyl phenazine methosulfate (mPMS), and $150 \mathrm{mmol} / \mathrm{L}$ $\mathrm{NaCl}^{29)}$ mPMS can diffuse across the plasma membrane, and it undergoes non-enzymatic reduction by cytosolic NAD $(\mathrm{P}) \mathrm{H}$. The reduced mPMS then diffuses out of cells and reduces extracellular WST-8 non-enzymatically. Thus, the formazan formation reflects the cellular ability to regenerate $\mathrm{NAD}(\mathrm{P}) \mathrm{H}$.

After neoechinulin A treatment for $24 \mathrm{~h}$, culture medium was replaced with a fresh medium containing $10 \%$ (v/v) kit-8 solution, and cells were incubated for the indicated times. The medium was transferred to a new 96-well assay plate, and A450 was measured on a plate reader. The values were normalized by the amount of protein in the respective wells.

Detection of Cellular Superoxide Production Cellular superoxide production was measured using the fluorescent dye dihydroethidium (DHE) under fluorescent microscopy. ${ }^{30)}$ Cells in 8-chamber culture slide (BD Falcon 354108) were treated with neoechinulin A $(100 \mu \mathrm{mol} / \mathrm{L})$ or its vehicle $(0.1 \%$ DMSO $)$ for $24 \mathrm{~h}$ and then incubated with DHE $(10 \mu \mathrm{M})$ in serum-free RPMI medium for $40 \mathrm{~min}$ in a $\mathrm{CO}_{2}$ incubator. Cells were washed three times with the medium, and images were acquired from seven randomly chosen fields using an inverted epifluorescence microscope (Axiovert-200, Carl Zeiss) with constant settings. Average fluorescence intensity per cell in each field was quantitated using Image J software (NIH). To achieve a maximum DHE oxidation, antimycin A $(10 \mu \mathrm{M})$ was added simultaneously with DHE.

Other Assays Protein concentration was determined by a BCA method (Pierce Biotechnology, Rockford, U.S.A.) using BSA as a standard.

Statistics Data were analyzed by Student's $t$-test or oneway analysis of variance (ANOVA) followed by Tukey's test. $p$ values less than 0.05 were considered significant. 


\section{RESULTS}

Neoechinulin A Treatment Renders PC12 Cells Resistant to Acute NO Toxicity We previously reported that treatment of NGF-differentiated PC12 cells with neoechinulin A for a minimum period of $12 \mathrm{~h}$ renders the cells resistant to subsequent challenge with $\mathrm{SIN}-1,{ }^{2)}$ an $\mathrm{O}_{2}^{-} / \mathrm{NO}$ cogenerator with a half-life of approximately $30 \mathrm{~min}^{31)}$ Although SIN-1-induced cytotoxicity in cultured cells is generally assumed to result from $\mathrm{ONOO}^{-}$, the reaction product of $\mathrm{O}_{2}^{-}$and $\mathrm{NO}$, our recent study suggested that the toxic entity of SIN-1 in PC12 cell culture is not $\mathrm{ONOO}^{-}$per se, but is a reaction product of $\mathrm{O}_{2}^{-}$/ NO generated in the culture medium. ${ }^{31)}$ Thus, the system is too complicated for a mechanistic study with neoechinulin A. To gain insight into the cytoprotective mechanism of neoechinulin A, we first assessed whether neoechinulin A treatment for $24 \mathrm{~h}$ could also confer resistance to other oxidative and/ or nitrosative stressors. To this end, two NO donors with different half-lives, NOR-3 $\left(t_{1 / 2}=30 \mathrm{~min}\right)^{32)}$ and DETA-NONOate $\left(t_{1 / 2}=20 \mathrm{~h}\right),{ }^{33)}$ were employed for $\mathrm{NO}$ toxicity, and bolus $\mathrm{H}_{2} \mathrm{O}_{2}$ and menadione were employed for oxidative cytotoxicity studies. The naphthoquinone menadione generates $\mathrm{O}_{2}^{-}$and $\mathrm{H}_{2} \mathrm{O}_{2}$ through redox cycling reactions consuming cellular NADPH and also causes arylation of thiols in cellular proteins, thus imposing a severe compound oxidative stress on cells. ${ }^{14)}$

Neoechinulin A $(100 \mu \mathrm{mol} / \mathrm{L})$ treatment for $24 \mathrm{~h}$ resulted in significant resistance to subsequent challenge with SIN-1, in agreement with previous studies ${ }^{2,7,8)}$; the $\mathrm{LD}_{50}$ was doubled from $0.6 \mathrm{mmol} / \mathrm{L}$ to $1.2 \mathrm{mmol} / \mathrm{L}$ (Fig. $2 \mathrm{~A}$ ). Neoechinulin $\mathrm{A}$ treatment also significantly ameliorated the cytotoxicity of NO from NOR-3; the $\mathrm{LD}_{50}$ increased from $120 \mu \mathrm{mol} / \mathrm{L}$ to $180 \mu \mathrm{mol} / \mathrm{L}$ (Fig. 2B). Cytoprotection against NO was also observed at a lower neoechinulin A concentration of $50 \mu \mathrm{mol} / \mathrm{L}$, but the extent was far less than that observed at $100 \mu \mathrm{mol} / \mathrm{L}$ (data not shown). Notably, however, neoechinulin A treatment did not at all confer protection against DETA-NONOate, another NO donor with a longer half-life (Fig. 2C). Moreover, neoechinulin A also failed to show substantial protection against bolus $\mathrm{H}_{2} \mathrm{O}_{2}$ (Fig. 2D) or menadione (Fig. 2E); in fact, neoechinulin $\mathrm{A}$ treatment slightly potentiated the cytotoxicity of menadione. The protective effects of neoechinulin A treatment against SIN-1 and NOR-3 were also confirmed by MTT assay (Fig. 3). These results suggest that neoechinulin A preferentially confers cytoprotection against acute or transient nitrosative stresses caused by $\mathrm{NO}$ or NO-derived reactive species (i.e., SIN-1), but not against persistent NO stress or oxidative stresses caused by agents other than NO.

Similarities of Neoechinulin A-Mediated Cytoprotection against SIN-1- and NOR-3-Induced Cytotoxicities Previous studies on the structure-activity relationship demonstrated that the $\mathrm{C} 8 / 9$ double bond of neoechinulin A, which constitutes a conjugated system from the indole to the diketopiperazine ring, is an essential structural feature for the cytoprotective action of the alkaloid against SIN-1; substitution of the double bond with a single bond (preechinulin, Fig. 1B) abolishes the cytoprotective activity. ${ }^{8)}$ To clarify whether the C8/9 double bond is also essential for the cytoprotective action against transient NO toxicity, the effect of preechinulin was addressed. As shown in Fig. 4A, the cytoprotective activity of preechinulin against NOR-3 toxicity was marginal, demonstrating that the $\mathrm{C} 8 / 9$ double is also an important structural feature for cytoprotection against transient NO stress.

Our previous study also revealed that neoechinulin A treatment for more than $12 \mathrm{~h}$ was required to impart cytoprotection against SIN-1 toxicity in PC12 cells. ${ }^{2)}$ Therefore, we next addressed the minimum period of neoechinulin A treatment that can confer cytoprotection against NOR-3 toxicity. Cells were incubated with neoechinulin A or its vehicle for 1, 3, 12 , or $24 \mathrm{~h}$ and then exposed to NOR-3 $(100 \mu \mathrm{mol} / \mathrm{L})$ for $24 \mathrm{~h}$. Significant cytoprotection was observed when the duration of neoechinulin A treatment exceeded 12h (Fig. 4B), consistent with the case of SIN-1 toxicity. The requirement for $>12 \mathrm{~h}$ of pretreatment suggests that cellular alterations involving the induction of cytoprotective genes are possibly associated with the cytoprotective action of neoechinulin A against acute nitrosative stresses induced by SIN-1 or NOR-3.

Profiling of the Antioxidant Enzyme Activities of PC12 Cells Following Neoechinulin A Treatment To identify the cellular alterations induced by neoechinulin A treatment, we first focused on the antioxidant defense system. PC12 cells were incubated with $100 \mu \mathrm{mol} / \mathrm{L}$ neoechinulin A for $24 \mathrm{~h}$, and the activities of key antioxidant enzymes were measured in the cell lysates.

Total SOD activity $\left(2 \mathrm{O}_{2}^{-}+2 \mathrm{H}^{+} \rightarrow \mathrm{H}_{2} \mathrm{O}_{2}+\mathrm{O}_{2}\right)$, which reflects mostly cytosolic CuZnSOD, was similar between the control and neoechinulin A-treated cells (Table 1). Catalase resides in peroxisome and decomposes $\mathrm{H}_{2} \mathrm{O}_{2}$ therein. Interestingly, the activity of catalase $\left(2 \mathrm{H}_{2} \mathrm{O}_{2} \rightarrow 2 \mathrm{H}_{2} \mathrm{O}+\mathrm{O}_{2}\right)$ was slightly decreased by neoechinulin A treatment (Table 1). NQO reduces various quinone compounds obligatorily via two electrons $\left(Q+\mathrm{NADPH}+\mathrm{H}^{+} \rightarrow Q \mathrm{H}_{2}+\mathrm{NADP}^{+}\right.$, where $Q$ represents a quinone compound), thereby preventing $\mathrm{O}_{2}^{-}$formation through semiquinone radical autoxidation. ${ }^{14)}$ However, if hydroquinone is unstable to autoxidation, as in the case of menadione, it may act as a deleterious ROS producing enzyme. ${ }^{34)}$ However, no difference in NQO activity was observed between the control and neoechinulin A-treated cells (Table 1).

GSH is a prime cellular antioxidant compound and is a critical co-substrate for GSH-dependent antioxidant/ detoxification enzymes. Unexpectedly, however, GSH content was decreased by $>50 \%$ by neoechinulin A treatment (Table 1). GPx is the cytosolic enzyme responsible for the elimination of $\mathrm{H}_{2} \mathrm{O}_{2}$ and lipid peroxides using $\mathrm{GSH}$ $\left(2 \mathrm{GSH}+\mathrm{LOOH} \rightarrow \mathrm{GSSG}+\mathrm{LOH}+\mathrm{H}_{2} \mathrm{O}\right.$, where $\mathrm{LOOH}$ represents a lipid peroxide). The GPx activity of cells was slightly decreased with neoechinulin A treatment, although the change was not statistically significant. GR reduces GSSG back to $\mathrm{GSH}\left(\mathrm{GSSG}+\mathrm{NADPH}+\mathrm{H}^{+} \rightarrow 2 \mathrm{GSH}+\mathrm{NADP}^{+}\right.$). GST accelerates the nucleophilic reaction of GSH with various electrophiles ( $\mathrm{GSH}+\mathrm{X} \rightarrow \mathrm{GS}-\mathrm{X}$, where $\mathrm{X}$ is an electrophile). No differences were observed in these GSH system enzymes after neoechinulin A treatment. GSNOR, originally identified as a member of alcohol dehydrogenase class III, is responsible for the reductive breakdown of GSNO (GSNO+NADH $+\mathrm{H}^{+} \rightarrow$ glutathione sulfonamide $+\mathrm{NAD}^{+}$). ${ }^{35)}$ Several studies reported that GSNOR plays an important role in defense against nitrosative stresses. $^{36,37)}$ However, no elevation in GSNOR activity was observed by neoechinulin A treatment (Table 1). In parallel with the GSH system, cells also deploy another thiol-based antioxidant system, the Trx/Trx reductase (TrxR) system. We measured the activity of $\operatorname{TrxR}\left[\operatorname{Tr} x-\mathrm{S}_{2}+\mathrm{NADPH}+\mathrm{H}^{+} \rightarrow \operatorname{Trx}-\right.$ $\left.(\mathrm{SH})_{2}+\mathrm{NADP}^{+}\right]$by using as an alternative substrate, DTNB. 
A

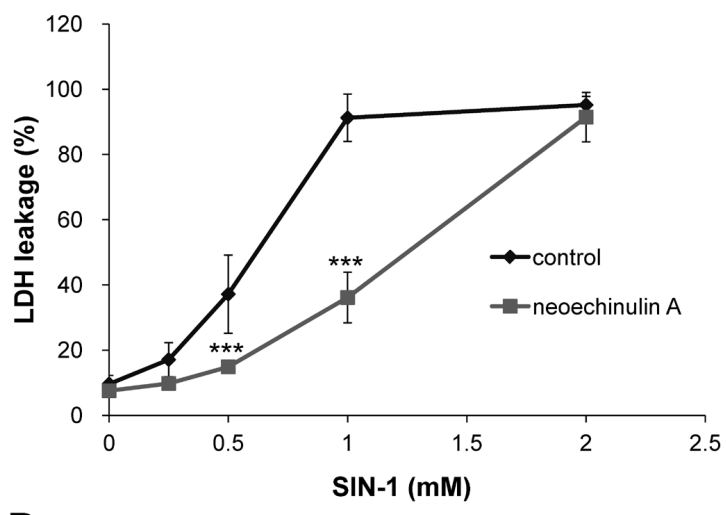

B

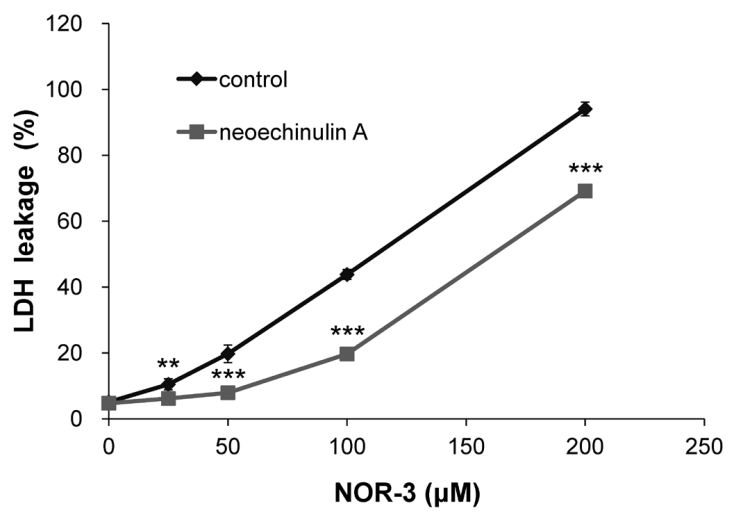

C

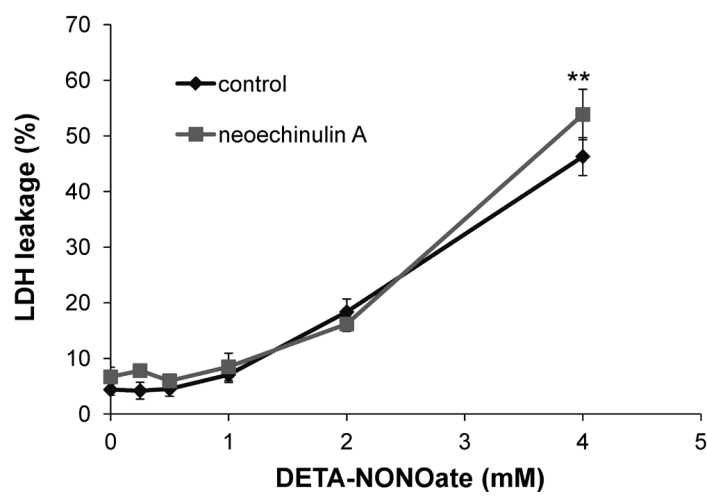

D

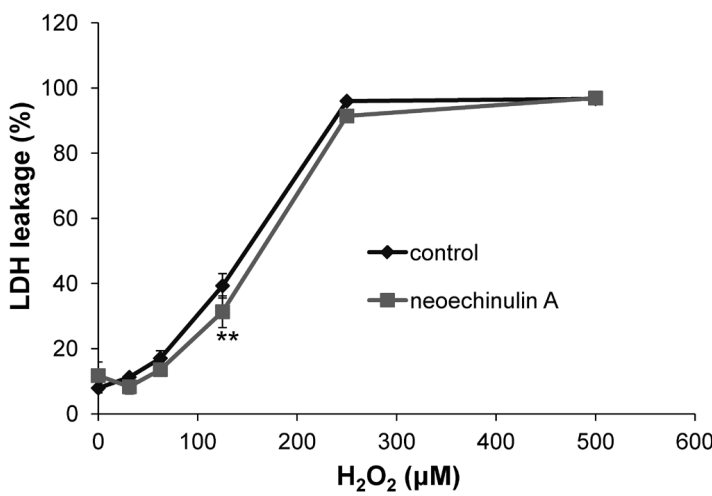

E

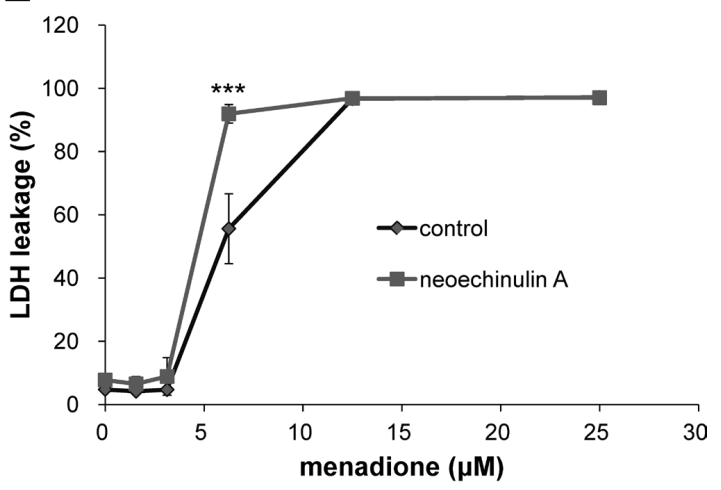

Fig. 2. Effect of Neoechinulin A Treatment on the Cytotoxicity of Various Oxidative/Nitrosative Stresses

Differentiated PC12 cells in 96-well plates were incubated with neoechinulin A $(100 \mu \mathrm{mol} / \mathrm{L})$ or its vehicle $(0.1 \%$ DMSO) for $24 \mathrm{~h}$, followed by exposure to the indicated concentrations of SIN-1 (A), NOR-3 (B), DETA-NONOate (C), $\mathrm{H}_{2} \mathrm{O}_{2}$ (D), or menadione (E) in a fresh medium for an additional $24 \mathrm{~h}$. Cell viability was assessed by LDH leakage $(\%)$ in each well. The values shown are the mean \pm intra-assay deviation expressed as the S.D. from four or five wells in a representative experiment. $* * p<0.01$; $* * * p<0.001$ vs. the respective control.

However, no difference was observed between the control and neoechinulin A-treated cells (Table 1). Overall, there results demonstrate that neoechinulin A paradoxically and selectively decreased GSH content without substantially affecting the activities of other antioxidant enzymes.

Characteristics of GSH Depletion Induced by Neoechinulin A To gain insight into the mechanism and biological significance of GSH depletion induced by neoechinulin A treatment, the time course for the decrease in cellular GSH content was measured (Fig. 5A). After adding fresh medium, GSH content in the control cells increased gradually.
However, in the neoechinulin A-treated cells, GSH was severely depleted by $8 \mathrm{~h}$, and its levels remained decreased up to $16 \mathrm{~h}$, after which its levels slightly increased over the next $8 \mathrm{~h}$. In fact, an approximately $50 \%$ decrease in GSH levels could be observed at as early as $3 \mathrm{~h}$ (data not shown). Interestingly, when cells were incubated with preechinulin, GSH levels were almost unchanged throughout the 24-h incubation period. Because the acid-soluble extract used for the GSH recycling assay may contain a metabolite of neoechinulin A or preechinulin that can interference with the enzymatic GSH assay and thereby artifactually decrease GSH readouts, a known 
A

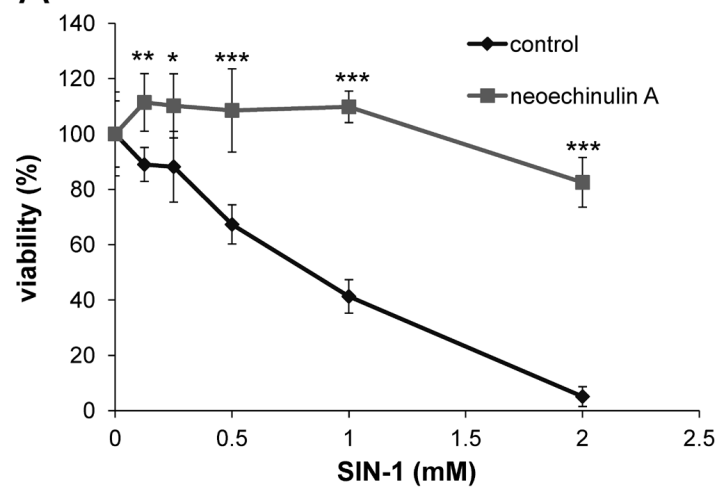

B

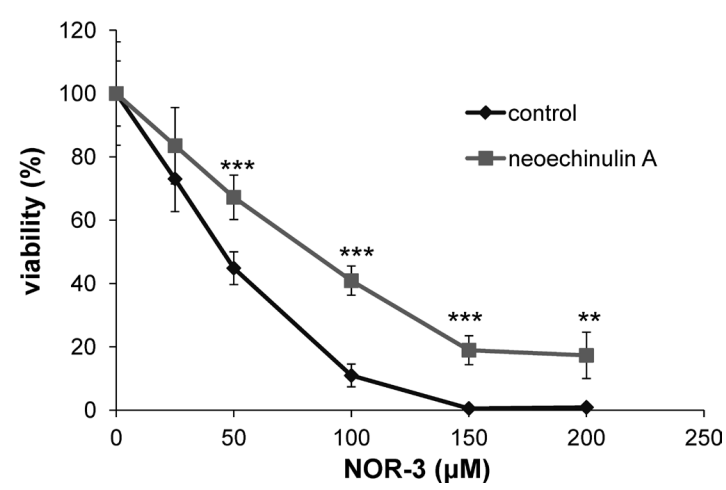

Fig. 3. Evaluation of the Cytoprotective Effect of Neoechinulin A against Cytotoxicities of SIN-1 and NOR-3

Control and neoechinulin A-treated cells were exposed to the indicated concentrations of SIN-1 (A) or NOR-3 (B) as in Fig. 2. Cell viability was measured by the MTT assay. The values shown are the mean \pm intra-assay deviation expressed as the S.D. from four or five wells in a representative experiment. $* p<0.05 ; * * p<0.01$ $* * * p<0.001 v s$. the respective control.

concentration of GSH was added to the acid-soluble extract from neoechinulin A- or preechinulin-treated cells, which were then subjected to the GSH recycling assay. Essentially no interference effect was observed for either extract (data not

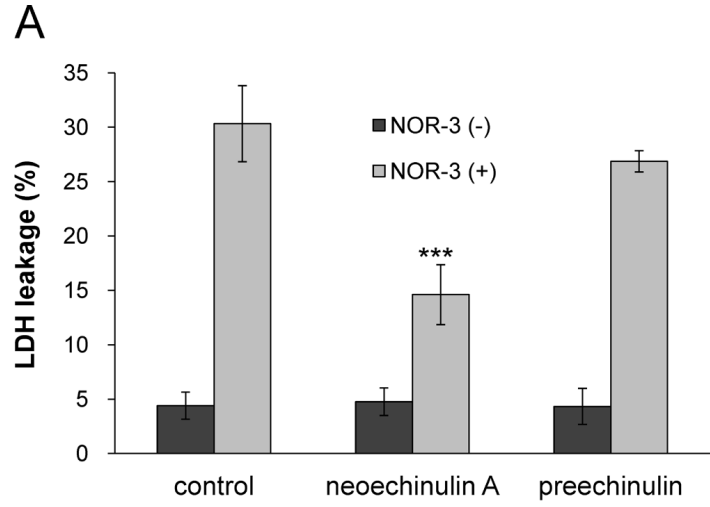

B

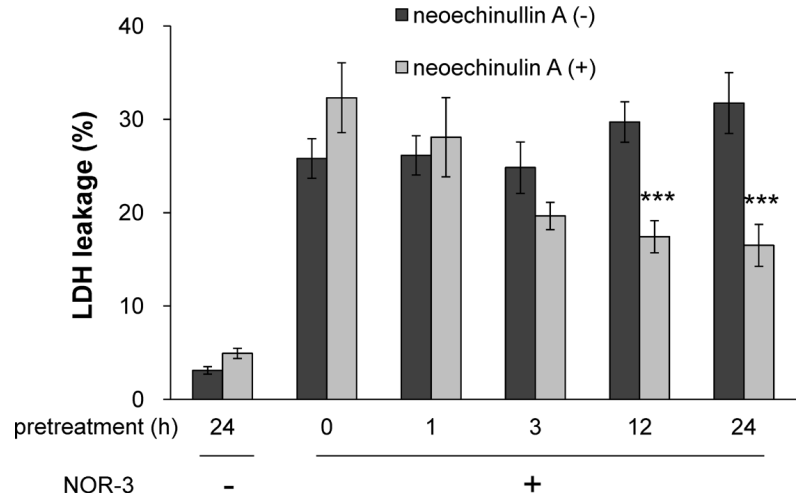

Fig. 4. Effects of Preechinulin and the Treatment Time of Neoechinulin A on the Cytotoxicity of NOR-3

(A) Comparison of the effects of preechinulin and neoechinulin A on NOR-3 cytotoxicity. Cells were pretreated in the same manner described in the legend to Fig. 2 and then exposed to NOR-3 $(100 \mu \mathrm{mol} / \mathrm{L})$. (B) Effect of neoechinulin A treatment time on the acquisition of resistance to NO cytotoxicity. Cells were treated as described in (A). In both (A) and (B), LDH leakage (\%) was measured $24 \mathrm{~h}$ after NOR-3 treatment. The values shown are the mean \pm intra-assay deviation expressed as the S.D. from four or five wells in a representative experiment. $* * * p<0.001 v s$. the respective control.

shown), thus verifying the results. Thus, neoechinulin A did

Table 1. Effect of Neoechinulin A Treatment for $24 \mathrm{~h}$ on the Activities of Antioxidant Enzymes and GSH Content in PC12 Cells

\begin{tabular}{|c|c|c|c|c|c|}
\hline $\begin{array}{c}\text { Antioxidant enzyme or } \\
\text { GSH }\end{array}$ & Unit & NeoA $(-)$ & NeoA $(+)$ & $\%$ & $p$ \\
\hline Superoxide dismutase & $\mathrm{U} / \mathrm{mg}$ & $21.6 \pm 1.4$ & $22.2 \pm 1.8$ & 102 & $\mathrm{~ns}$ \\
\hline Catalase & $\mathrm{U} / \mathrm{mg}$ & $2.04 \pm 0.05$ & $1.75 \pm 0.14$ & 86 & $*$ \\
\hline $\begin{array}{l}\text { NAD }(\mathrm{P}) \mathrm{H} \text { quinone } \\
\text { oxideredactase } 1 \\
\text { (NQO 1) }\end{array}$ & $\mathrm{mU} / \mathrm{mg}$ & $9.7 \pm 2.1$ & $9.2 \pm 1.7$ & 95 & $\mathrm{~ns}$ \\
\hline Glutathione (GSH) & $\mathrm{nmol} / \mathrm{mg}$ & $18.7 \pm 0.5$ & $8.4 \pm 1.0$ & 45 & $* * *$ \\
\hline $\begin{array}{l}\text { Gurutathione reductase } \\
\text { (GR) }\end{array}$ & $\mathrm{mU} / \mathrm{mg}$ & $62.7 \pm 2.4$ & $60.3 \pm 2.8$ & 97 & $\mathrm{~ns}$ \\
\hline $\begin{array}{l}\text { Glutathione } S \text {-transfer- } \\
\text { ase (GST) }\end{array}$ & $\mathrm{mU} / \mathrm{mg}$ & $11.2 \pm 1.2$ & $11.0 \pm 0.0$ & 98 & $\mathrm{~ns}$ \\
\hline $\begin{array}{l}\text { Glutathione peroxidase } \\
\text { (GPx) }\end{array}$ & $\mathrm{mU} / \mathrm{mg}$ & $20.4 \pm 0.8$ & $17.5 \pm 1.5$ & 86 & ns \\
\hline $\begin{array}{l}\text { GSNP reductase (GS- } \\
\text { NOR) }\end{array}$ & $\mathrm{mU} / \mathrm{mg}$ & $19.5 \pm 2.0$ & $20.7 \pm 2.1$ & 106 & ns \\
\hline $\begin{array}{l}\text { Thioredoxin reductase- } \\
\text { like (TrxR-like) }\end{array}$ & $\mathrm{mU} / \mathrm{mg}$ & $16.5 \pm 1.0$ & $15.5 \pm 1.5$ & 94 & ns \\
\hline
\end{tabular}

NGF-differentiated PC12 cells were treated with neoechinulin A $(100 \mu \mathrm{mol} / \mathrm{L})$ or its vehicle $(0.1 \%$ DMSO) for $24 \mathrm{~h}$. Cells were lyzed using Triton X-100, and the GSH content and antioxidant enzyme activities of the Triton X-100-soluble fraction were measured. Values are presented as the mean \pm intra-assay deviation expressed as the S.D. from three cultures. Each data set shown is one representative result from two independent experiments. ${ }^{*} p<0.05 ; * * * p<0.001 v s$. control. 
A

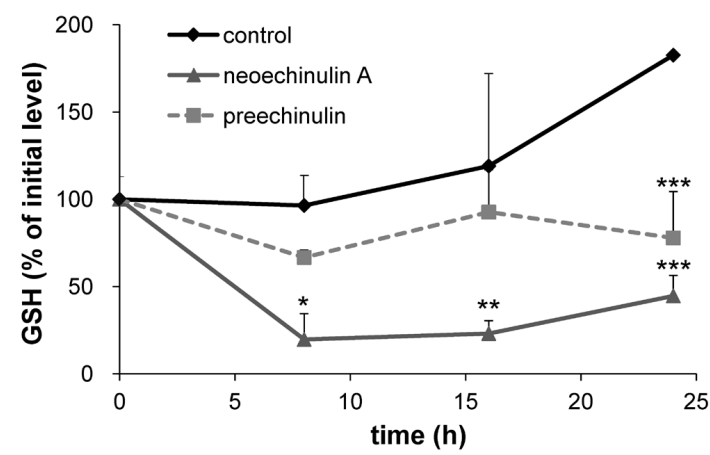

B

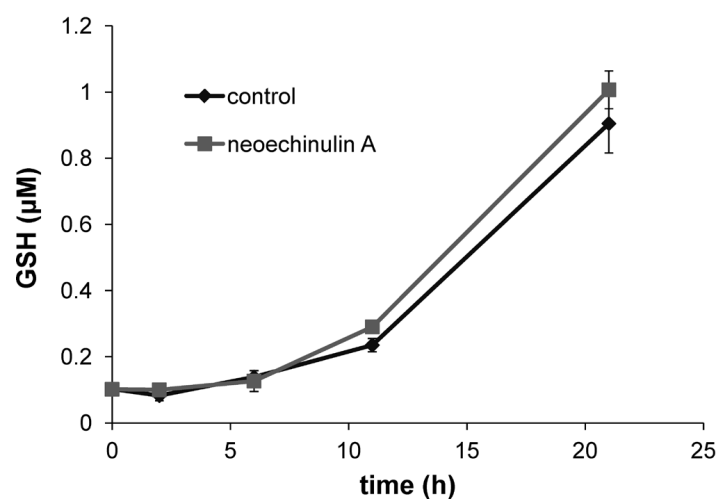

C

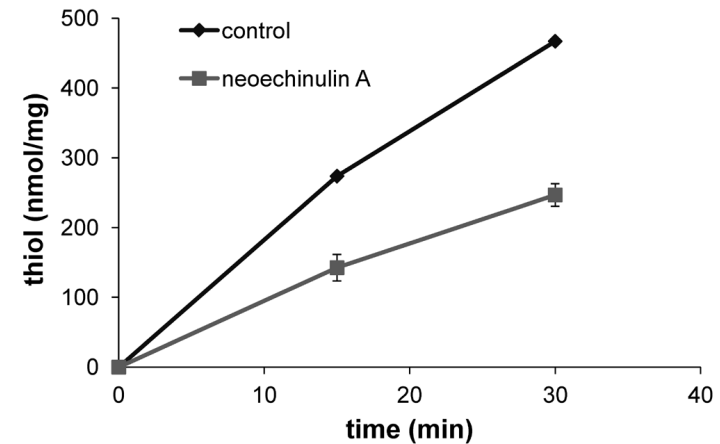

D

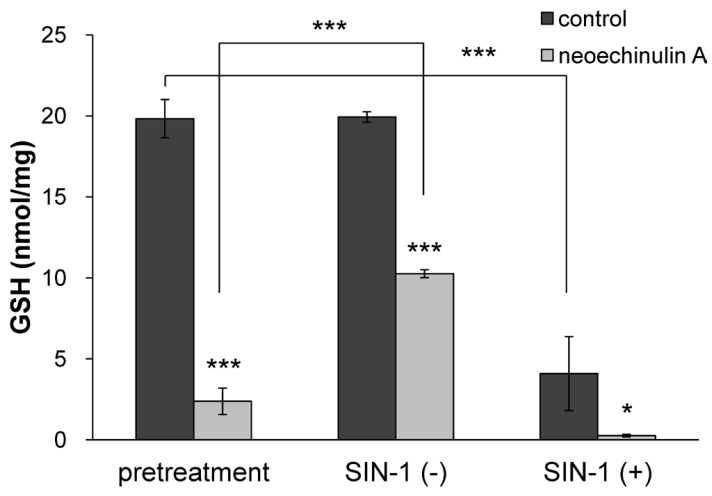

Fig. 5. Effects of Neoechinulin A and Preechinulin Treatments on Cellular GSH Content, Disulfide Reductase Activity, and Response to SIN-1

(A) Time course of the change in cellular GSH content. Cells in 6-well plates were incubated with neoechinulin A or preechinulin (each $100 \mu$ mol/L) or their vehicle $(0.1 \%$ DMSO) for the indicated times, and GSH content in the cells was measured. Values are presented as the mean \pm intra-assay deviation expressed as the S.D. from three wells in a representative experiment. (B) Time course of GSH accumulation in the medium. In a separate experiment, GSH concentrations in the culture medium after incubation with or without neoechinulin A $(100 \mu \mathrm{mol} / \mathrm{L})$ were measured. (C) Changes in cellular disulfide reductase activity by neoechinulin A treatment. Cells in 12 -well plates were treated with neoechinulin A $(100 \mu \mathrm{mol} / \mathrm{L})$ or its vehicle $(0.1 \%$ DMSO) for $24 \mathrm{~h}$. The medium was removed, and the cells were washed with PBS and incubated with HDES $(\mu \mathrm{mol} / \mathrm{L})$ in PBS containing glucose, $\mathrm{Ca}^{2+}$, and $\mathrm{Mg}^{2+}$ for the indicated times. The levels of 2-mercaptoethanol in the medium were measured by the DTNB assay. The values are presented as the mean \pm intra-assay deviation expressed as the range of two wells in a representative experiment. (D) Effect of neoechinulin A treatment on SIN-1-induced depletion of cellular GSH. Cells in 6-well plates were incubated with or without neoechinulin A (100 $\mu$ mol/L) for $24 \mathrm{~h}$ (noted as "pretreatment") and then incubated with or without SIN-1 ( $1 \mathrm{mmol} / \mathrm{L})$ in a fresh medium for an additional $2 \mathrm{~h}$. Cytosolic GSH content was measured as described above. Values are presented as the mean \pm intra-assay deviation expressed as the SD of three wells in a representative experiment. For (A), (B), and (D), $* p<0.05 ; * * p<0.01 ; * * * p<0.001 v s$. the respective control. In (D), comparisons with other groups are also shown.

cause a decrease in cellular GSH content in PC12 cells.

It is documented that cells continuously export GSH and increase the efflux rate of GSH when exposed to certain compounds such as polyphenols ${ }^{38)}$ and diphenyleneiodonium. ${ }^{39)}$ To investigate whether the decrease in GSH content induced by neoechinulin A treatment was due to an increase in the rate of GSH efflux, we measured the level of extracellular GSH (Fig. 5B). After adding fresh medium, the GSH concentration in the medium increased gradually over the 20 -h incubation period. However, no difference was observed between the control and neoechinulin A-treated cells.

We next examined whether the decrease in GSH content in the neoechinulin A-treated cells was reflected by the cellular redox phenotype. Reduction of exogenous 2-hydroxyethyl disulfide to 2-mercaptoethanol by live cells has been demonstrated to be catalyzed by thioltransferase glutaredoxin and significantly dependent on the substrate of the enzyme, $\mathrm{GSH}^{28)}$ 2-hydroxyethyl disulfide reductase activity in the neoechinulin A-treated cells was also decreased to $50 \%$ of that in the control cells (Fig. 5C), suggesting that the decrease in the levels of cellular GSH induced by neoechinulin A leads to decreased disulfide reductase activity in the cells.
Exposure to NO or SIN-1 has been demonstrated to result in GSH depletion in a range of cells via various mechanisms. ${ }^{40-43)}$ We next examined whether the neoechinulin A-treated cells undergo further GSH depletion in response to SIN-1. After treatment with neoechinulin A for $24 \mathrm{~h}$, cells were challenged with SIN-1 for $2 \mathrm{~h}$, and cellular GSH content was measured (Fig. 5D). Cellular GSH levels were decreased to approximately $20 \%$ of those of untreated cells after neoechinulin A treatment. Without subsequent SIN-1 treatment, GSH levels recovered to $50 \%$ of the original levels within the next $2 \mathrm{~h}$. By contrast, exposure to SIN-1 for $2 \mathrm{~h}$ caused a severe GSH depletion in the neoechinulin A-treated cells and in the control cells. Thus, neoechinulin A-treated cells cannot prevent further depletion of residual GSH under acute nitrosative stress conditions.

Profiling of Metabolic Enzyme Activities of PC12 Cells Following Neoechinulin A Treatment We next investigated cellular alterations induced by neoechinulin A treatment for $24 \mathrm{~h}$, focusing on metabolic pathways responsible for supplying NADPH for antioxidant systems and ATP production. Phosphorylation of glucose by $\mathrm{HK}$ is the first step of glucose catabolism (glucose $+\mathrm{ATP} \rightarrow \mathrm{G} 6 \mathrm{P}+\mathrm{ADP})$. The product G6P 
then undergoes oxidative breakdown reactions in either the pentose phosphate pathway (PPP) or the glycolytic pathway followed by the Krebs cycle pathway. HK activity was not different between the control and neoechinulin A-treated cells (Table 2).

The NADPH level is a critical factor for the functions of an array of cellular antioxidant enzymes. From G6P as an initial substrate, NADPH is produced by successive reactions catalyzed by two PPP enzymes, namely, the rate-limiting enzyme $\mathrm{G} 6 \mathrm{PDH}\left(\mathrm{G} 6 \mathrm{P}+\mathrm{NADP}^{+}+\mathrm{H}^{+} \rightarrow 6\right.$ P-glucono- $\delta$-lactone+NADPH) and the second enzyme $\quad 6 \mathrm{PGDH} \quad$ (6-P-glucono- $\delta$-lactone $+\mathrm{NADP}^{+}+\mathrm{H}^{+} \rightarrow$ 6-P-gluconate+NADPH). NADPH may also be supplied from the Krebs cycle by the action of $\mathrm{ICDH}^{26)}$ No differences were observed in the activities of any of these NADPHproducing enzyme in response to neoechinulin A treatment (Table 2). We then measured the activities of two glycolytic enzymes responsible for NADH metabolism: $\mathrm{LDH}$ (pyruvate $+\mathrm{NADH}+\mathrm{H}^{+} \rightarrow$ lactate) and GAPDH (glyceraldehyde $3-\mathrm{P}+\mathrm{NAD}^{+}+\mathrm{P} i \rightarrow \mathrm{D}$-glycerate $1,3-\mathrm{BP}+\mathrm{NADH}+\mathrm{H}^{+}$). There was also no difference in the activity of either enzyme between the control and neoechinulin A-treated cells (Table 2). CS (acetyl $\mathrm{CoA}+$ oxaloacetate $\rightarrow$ citrate $+\mathrm{CoA})$ is a Krebs cycle enzyme, and its activity is generally reflected by the number of the mitochondria in a cell. ${ }^{44)}$ No difference was observed for CS activity between the control and neoechinulin A-treated cells (Table 2).

We also measured proteasome activity; however, no difference was observed between the control and neoechinulin A-treated cells (Table 3). It is known that cells have various enzymes that can catalyze the reduction of NBT to its formazan using either NADH or NADPH (so-called diaphorase activity). A part of the activity with the latter substrate has been attributed to neuronal nitric oxide synthase (nNOS). ${ }^{45)}$ In PC12 cells, diaphorase activity with NADPH was 2-fold higher than that with NADH (Table 3). However, there was no difference in either NADH- or NADPH-linked diaphorase activity in lysates from the control and neoechinulin A-treated cells. Thus, overall, neoechinulin A treatment did not affect the activities of metabolic enzymes.

Neoechinulin A Treatment Elevates the Apparent Cellular Capacity to Generate NAD(P)H The phenazine-mediated reduction of extracellular WST- 8 assay is an index of cellular capacity to generate $\mathrm{NAD}(\mathrm{P}) \mathrm{H},{ }^{29)}$ and it is widely used for live cell counting in viability and proliferation assays. Previous studies revealed that neoechinulin A treatment elevates the WST-8-reducing capacity of PC12 cells and that a correlation exists between a potentiation of WST-8-reducing activity and an increase in resistance to SIN-1-induced cytotoxicity with several neoechinulin A analogs. ${ }^{2)}$ However, it remained unclear whether preechinulin can also elevate this activity. Therefore, we compared the cellular WST-8-reducing activity of neoechinulin A- and preechinulin-treated cells (Fig. 6A). After incubation with WST and phenazine, WST-8 formazan levels increased linearly with time in the control cell cultures. Consistent with previous findings, ${ }^{2)}$ the formazan formation rate was approximately $40 \%$ higher in the neoechinulin Atreated cells than in the control cells. By contrast, there was no increase in the formazan formation rate in cells treated with preechinulin. These results further support that the WST8-reducing activity is linked with the cytoprotective mechanism of neoechinulin A against acute nitrosative stresses and that the presence of the $\mathrm{C} 8 / 9$ double bond is responsible for the alterations. When $\mathrm{O}_{2}$-dependent $\mathrm{NADH}$ oxidation was facilitated by the uncoupler CCCP, WST-8 reduction rates were significantly decreased to almost the same level in control and neoechinulin A-treated cells (Fig. 6A, inset graph), confirming the involvement of NADH in WST-8 reduction.

To investigate whether the elevated WST-8-reducing activity in the neoechinulin A-treated cells resulted from an increase in the reduced form of either pyridine nucleotide, the levels of NADH and NADPH and their redox states were analyzed (Fig. 6B). However, the total pools of NADH or NADPH as well as the reduced-to-oxidized ratio were not substantially different between the control and neoechinulin A-treated cells. Because various tetrazoliums including WST-1, a close

Table 2. Effect of Neoechinulin A Treatment for $24 \mathrm{~h}$ on the Activities of Metabolic Enzymes in PC12 Cells

\begin{tabular}{lccccc}
\hline \multicolumn{1}{c}{ Metabolic enzyme } & Unit & NeoA (-) & Neo (+) & $\%$ & $p$ \\
\hline Hexokinase (HK) & $\mathrm{mU} / \mathrm{mg}$ & $23.1 \pm 1.8$ & $22.9 \pm 2.0$ & 99 & $\mathrm{~ns}$ \\
Glucose-6-phosphate dehydrogenase (G6PDH) & $\mathrm{mU} / \mathrm{mg}$ & $52.6 \pm 3.3$ & $52.3 \pm 1.4$ & 99 & $\mathrm{~ns}$ \\
6-Phosphogluconete dehydrogenase (6PGDH) & $\mathrm{mU} / \mathrm{mg}$ & $12.8 \pm 0.4$ & $12.3 \pm 0.5$ & 96 & $\mathrm{~ns}$ \\
NADPH-isocitrate dehydrogenase (ICDH) & $\mathrm{mU} / \mathrm{mg}$ & $55.5 \pm 1.9$ & $57.2 \pm 2.3$ & $\mathrm{~ns}$ & $\mathrm{~ns}$ \\
Lactate dehydrogenase (LDH) & $\mathrm{U} / \mathrm{mg}$ & $4.4 \pm 0.5$ & $4.4 \pm 0.5$ & 100 & $\mathrm{~ns}$ \\
Glyceraldehyde 3-phosphate dehydrogenase & $\mathrm{mU} / \mathrm{mg}$ & $78.6 \pm 6.7$ & $85.7 \pm 5.0$ & 109 & 100 \\
$\quad$ & & & $127 \pm 2$ & $\mathrm{~ns}$
\end{tabular}

Using the same cell lysates described for Table 1, metabolic enzyme activities were measured. Values are presented as the mean \pm intra-assay deviation expressed as the S.D. from three cultures. Each data set shown is one representative result from two independent experiments.

Table 3. Effect of Neoechinulin A Treatment for $24 \mathrm{~h}$ on the Activities of Proteasome and Other Enzymes in PC12 Cells

\begin{tabular}{|c|c|c|c|c|c|}
\hline Others & Unit & NeoA (-) & NeoA $(+)$ & $\%$ & $p$ \\
\hline Proteasome & $\mathrm{mU} / \mathrm{mg}$ & $2.36 \pm 0.09$ & $2.20 \pm 0.04$ & 93 & ns \\
\hline NADH-diaphorase & $\mathrm{mAbs} / \mathrm{mg}$ & $50.7 \pm 1.4$ & $51.8 \pm 5.6$ & 102 & ns \\
\hline NADPH-diaphorase & $\mathrm{mAbs} / \mathrm{mg}$ & $94.9 \pm 4.3$ & $100.0 \pm 8.7$ & 105 & ns \\
\hline
\end{tabular}

Using the same cell lysates in Table 1, the trypsin-like activity of proteasomes and diaphorase activities were measured. Values are presented as the mean \pm intra-assay deviation expressed as the SD from three cultures. Each data set shown is one representative result from two independent experiments. 
analogue of WST-8, can be used to detect $\mathrm{O}_{2}{ }^{-46},{ }^{46}$ it may be possible that an increase in WST- 8 reduction in neoechinulin A-treated cells may be due to an increase in $\mathrm{O}_{2}^{-}$production by the cells. Therefore, we compared cellular $\mathrm{O}_{2}^{-}$production between control and neoechinulin A-treated cells. As shown in Fig. 6C, neoechinulin A treatment did not increase basal $\mathrm{O}_{2}^{-}$production or antimycin A-stimulated mitochondrial $\mathrm{O}_{2}{ }^{-}$ production, thus ruling out the possibility of the elevation of $\mathrm{O}_{2}^{-}$production in neoechinulin A-treated cells. Taken together, these results suggest that neoechinulin A-treated cells can enhance $\mathrm{NAD}(\mathrm{P}) \mathrm{H}$ recycling activity only when measured in intact cells.

\section{DISCUSSION}

In this study, we demonstrated that in PC12 cells, neoechinulin A afforded cytoprotection against acute NO stress induced by NOR-3 in addition to compound nitrosative stresses induced by SIN-1, but not, essentially, against persistent NO stress or oxidative stresses involving entities other than NO (Fig. 2). There are similarities regarding the cytoprotective mechanism of neoechinulin A between NOR-3- and SIN1-induced stresses. The half-lives of SIN-1 and NOR-3 are both relatively short (ca. $30 \mathrm{~min}) .^{31,32)}$ Preechinulin, which does not confer cytoprotection against SIN-1-induced toxicity, ${ }^{8)}$ also failed to confer protection against NO-induced toxicity (Fig. 4A). To provide the cells with cytoprotection against acute NO-induced toxicity, it is necessary to incubate the cells for more than $12 \mathrm{~h}$ with neoechinulin A (Fig. 4B), consistent with the case of SIN-1-induced toxicity. ${ }^{2}$ ) These results suggest that the specificity of cytoprotection afforded by neoechinulin A is limited to transient nitrosative stresses, and therefore, the cytoprotective mechanism for SIN-1 and NOR-3 toxicities is probably dependent on the same cellular alterations induced by this alkaloid.

Profiling of cellular alterations revealed that substantial differences were observed only for GSH depletion and elevation of cellular WST-8-reducting activity between control and neoechinulin A-treated cells (Tables 1-3, Fig. 6A). Importantly, preechinulin treatment caused neither severe GSH depletion (Fig. 5A) nor potentiation of WST-8-reducing activity (Fig. 6A), thus suggesting a relationship between these two alterations and the cytoprotective mechanism. Moreover, regarding WST-8-reducing activity, we previously found within a series of neoechinulin A analogs a correlation between an elevation in WST-8-reducing activity and resistance to SIN-1-induced toxicity. ${ }^{2}$ Thus, elevation in WST-8-reducing capacity in particular could deserve in-depth consideration in relation to the cytoprotective of mechanism of neoechinulin A treatment.

Neoechinulin A Treatment Enhances Cellular Reserve Capacity for NAD(P)H Redox Turnover, Which May Be Responsible for the Cytoprotective Mechanism In a wide variety of cells including neuronal cells, excessive NO has been demonstrated to inhibit oxygen $\left(\mathrm{O}_{2}\right)$ consumption by mitochondria, initially through competition with $\mathrm{O}_{2}$ for binding to cytochrome $c$ oxidase (complex IV) ${ }^{47)}$ and later by inflicting irreversible damage to the electron transport chain enzymes. ${ }^{47,48)} \mathrm{NO}$ and reactive species derived from SIN-1 have also been demonstrated to impair key metabolic enzymes such as GAPDH and $\mathrm{ICDH} .{ }^{26,49,50)}$ Consistent with the paradigm,

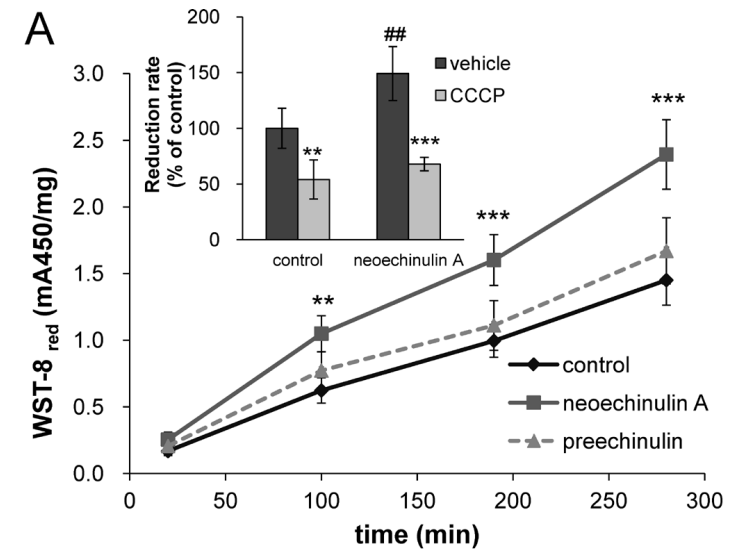

B
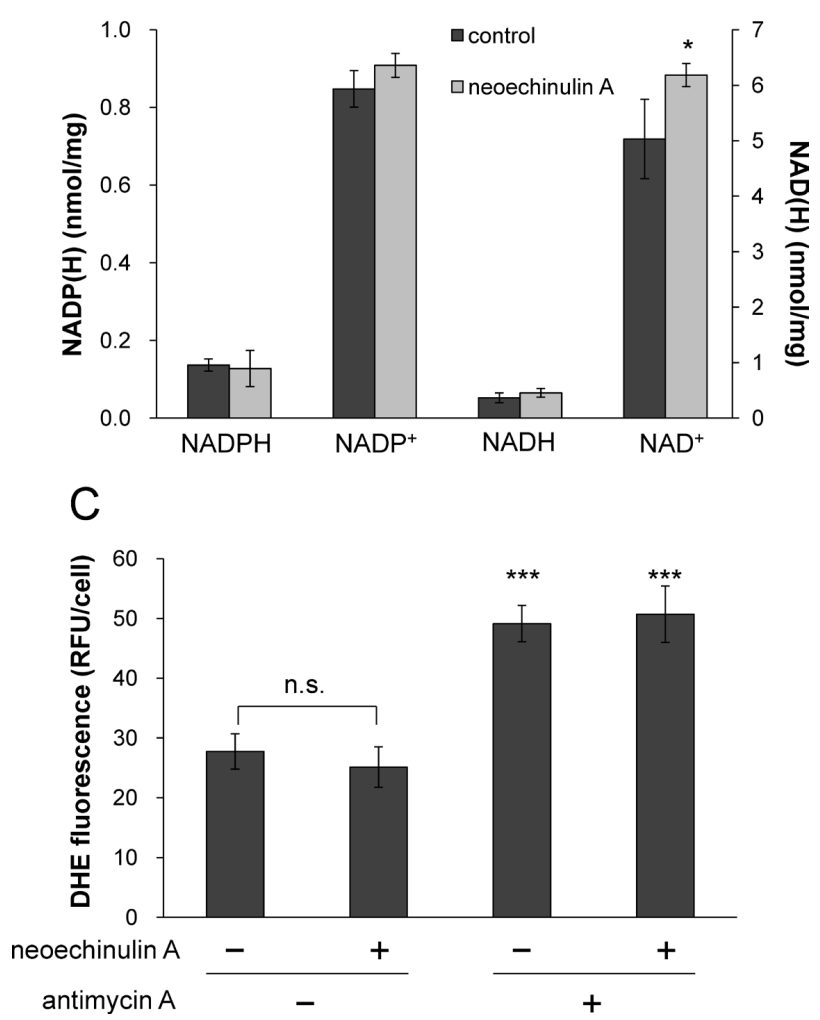

Fig. 6. Effects of Neoechinulin A and Preechinulin Treatments on the Tetrazolium-Reducing Activity of Cells and NAD(P)H Status

(A) Tetrazolium-reducing activity of intact cells. Cells in 96-well plates were incubated with neoechinulin A or preechinulin (each $100 \mu \mathrm{mol} / \mathrm{L}$ ) or their vehicle $(0.1 \%$ DMSO) for $24 \mathrm{~h}$ and then incubated with WST- 8 along with 1-methoxy phenazine methosulfate in a fresh medium. Formazan levels were measured at $450 \mathrm{~nm}$ and normalized by the concentration of protein. Values are presented as the mean \pm intra-assay deviation expressed as the S.D. of five wells in a representative experiment. $* * p<0.01 ; * * * p<0.001$ vs. the respective control. The inset graph shows the effect of the uncoupler CCCP on WST- 8 reduction. CCCP $(10 \mu \mathrm{mol} / \mathrm{L})$ was added in conjunction with WST- 8 . Values are presented as the mean \pm intraassay deviation expressed as the S.D. of five wells in a representative experiment. $* * p<0.01 ; * * * p<0.001 v s$. respective vehicle-treated cells. ${ }^{\#} p<0.01 v s$. vehicle-treated control. (B) NADP $(\mathrm{H})$ status of cells. After treatment without $(0.1 \%$ DMSO) or with neoechinulin A $(100 \mu \mathrm{mol} / \mathrm{L})$ in 6 -well plates, cellular pyridine nucleotide levels were quantitated by means of an enzyme-mediated NAD(P)H recycling-coupled MTT reduction assay. Values are presented as the mean \pm intraassay deviation expressed as the S.D. of three wells in a representative experiment. ${ }^{*} p<0.05$ vs. respective control (C) Intracellular superoxide generation. Cells in 8-chambert slide were treated with neoechinulin A $(100 \mu \mathrm{mol} / \mathrm{L})$ or its vehicle $(0.1 \%$ DMSO $)$ for $24 \mathrm{~h}$ and then incubated with DHE $(10 \mu \mathrm{mol} / \mathrm{L})$ for $40 \mathrm{~min}$ in serum-free medium in the absence or presence of antimycin A $(10 \mu \mathrm{mol} / \mathrm{L})$. Images were acquired from randomly chosen seven fields, and average fluorescence intensity was calculated. Values are presented as the mean \pm intra-assay deviation expressed as the SD of seven fields in a representative experiment. $* * * p<0.001 v s$. antimycin A (-) in respective cells. 
a previous study in $\mathrm{PC} 12$ cells demonstrated that treatment with NOR-3 resulted in inactivation of complex IV. ${ }^{51)}$ We also observed that SIN-1 treatment inactivated complexes IV and $\mathrm{V}$ in PC12 cells (data not shown). Glial cells are reported to withstand nitrosative stresses by shifting ATP production from oxidative phosphorylation to glycolysis, whereas neuronal cells cannot shift ATP production due to lack of this metabolic shifting machinery. ${ }^{52}$ Taken together, damage to energy-producing systems including mitochondria and consequent energy failure, ${ }^{42,53)}$ could partly be responsible for the cytotoxicity of acute nitrosative stresses in our system as well. One mechanism by which neoechinulin A-treated cells can withstand acute nitrosative stresses is, therefore, the elevation of the cellular reserve capacity for $\mathrm{NAD}(\mathrm{P}) \mathrm{H}$ redox turnover, as represented by the elevated WST-8-reducing capacity.

Reduction of extracellular WST-8 via intermediation of the membrane-permeable electron carrier mPMS, depends on the concentration of the reduced forms of either pyridine nucleotide. The elevation of cellular WST-8-reducting capacity on neoechinulin A treatment suggests that the cells have higher concentrations of $\mathrm{NAD}(\mathrm{P}) \mathrm{H}$. Nevertheless, neither the total concentration of $\mathrm{NAD}(\mathrm{H})$ or $\mathrm{NADP}(\mathrm{H})$ nor the ratios of their reduced-to-oxidized forms changed on neoechinulin A treatment (Fig. 6B). Moreover, none of the enzymes in PPP, the glycolytic pathway, or the Krebs cycle (Table 2) or even NAD(P)H-diaphorase activity (Table 3), was upregulated in the lysate from neoechinulin A-treated cells. These discrepant results can be reconciled if we assume that neoechinulin A-treated cells have gained the ability to increase the regeneration rate of $\mathrm{NAD}(\mathrm{P}) \mathrm{H}$ from $\mathrm{NAD}(\mathrm{P})^{+}$to a greater extent than control cells, only when $\mathrm{NAD}(\mathrm{P}) \mathrm{H}$ is being consumed for reduction of WST-8. In other words, neoechinulin A treatment can potentiate oxidant-driven $\mathrm{NAD}(\mathrm{P}) \mathrm{H}$ redox turnover rates (reserve capacity). In the absence of the oxidant WST-8, that is, in the resting state, $\mathrm{NAD}(\mathrm{P})^{+} / \mathrm{NAD}(\mathrm{P}) \mathrm{H}$ steady-state ratios could remain at a certain value irrespective of such elevated turnover capacity, as the results demonstrated (Fig. 6B). The same mechanism could become operative under nitrosative stresses. If a portion of a certain enzyme in $\mathrm{NAD}(\mathrm{P}) \mathrm{H}-$ producing pathways is inactivated by nitrosative stresses, an increase in the efficiency of the pathway as a whole induced by neoechinulin A treatment can compensate for the otherwise decreased production efficiency, and thereby sustain sufficient $\mathrm{NAD}(\mathrm{P}) \mathrm{H}$ production. Currently, it is technically difficult to delineate the pyridine nucleotide for which its redox turnover reserve capacity was elevated by neoechinulin A treatment, although in cell-free system analysis, WST- 8 reduction with NADH was approximately $30 \%$ faster than that with NADPH (data not shown).

Analogous situations have been reported for the cases of cellular respiratory reserve (or spare) capacity, which is defined as an increase in the $\mathrm{O}_{2}$ consumption rate induced by uncouplers (i.e., CCCP). ${ }^{54-56)}$ In this case, NADH oxidation is driven by $\mathrm{O}_{2}$ via intermediation of the electron transport chain enzymes, in contrast to WST-8 with the intermediacy of mPMS, and the NADH supply is at least one factor determining the magnitude of the capacity. ${ }^{54)}$ It has been demonstrated that various types of cells can withstand various stressors unless the reserve capacity collapses. ${ }^{44,55,56)}$ Forced oxidation of NADH by the presence of CCCP attenuated WST- 8 reduction in the control and neoechinulin A-treated cells to the same level (Fig. 6A, inset graph) suggests that NADH turnover is potentiated by neoechinulin A treatment.

Although the molecular mechanism for elevation of the reserve capacity for $\mathrm{NAD}(\mathrm{P}) \mathrm{H}$ turnover induced by neoechinulin A is not clear at present, one possible mechanism is that neoechinulin A treatment changes the intracellular localizations of some metabolic enzymes involved in $\mathrm{NAD}(\mathrm{P}) \mathrm{H}$ redox turnover. It has been reported that several enzymes of PPP and the glycolytic pathway are associated with mitochondria, ${ }^{57)}$ scaffold proteins, and cytoskeletal proteins, ${ }^{58-60)}$ and their interaction can be altered in response to certain treatments. ${ }^{60)}$ Cell lysis disrupts the interaction of enzymes, and therefore, activity of a component enzyme in the lysates displays no difference in the presence or absence of treatment. Thus, although the molecular details are not clear at present, elevation of the reserve capacity for $\mathrm{NAD}(\mathrm{P}) \mathrm{H}$ redox turnover induced by neoechinulin A treatment could compensate the damaged metabolic pathways resulting from nitrosative stresses, thereby affording resistance. Further studies are needed to clarify the molecular mechanism for this alteration.

Possibility of GSH Depletion as a Mechanism for Cytoprotection by Neoechinulin A Neoechinulin A treatment was associated with a selective decrease in GSH content (Table 1, Fig. 5A). This GSH decrease is unlikely due to increased efflux into the extracellular milieu (Fig. 5B). Although neoechinulin A, but not preechinulin, has a potential Michael acceptor site at $\mathrm{C} 8$, our cell-free study revealed that incubation of neoechinulin A with excess GSH overnight in the $\mathrm{pH}$ range of 7 to 9 did not result in adduct formation, as revealed by HPLC analysis (data not shown). Therefore, Michael adduct formation is unlikely to be the mechanism responsible for GSH depletion, although we could not completely rule out this possibility inside the cells because of the presence of GST. Thus, GST-mediated adduct formation, inhibition of its synthesis, and increase in their breakdown are remaining possibilities, which we need to be addressed in future research.

Whether GSH depletion plays a role in the cytoprotective mechanism of neoechinulin A is not definitive at present. However, it is well established that GSH is a pivotal cellular antioxidant against oxidative stresses and nitrosative stresses. $^{36,37,61)}$ This paradigm is also applicable to our $\mathrm{PC} 12$ cells; reduction of cellular GSH content by buthionine sulfoxide (BSO), a specific inhibitor of $\gamma$-glutamyl-cysteine ligase, rendered PC12 cells significantly susceptible to SIN-1-mediated cytotoxicity ${ }^{31)}$ and to NOR-3-mediated toxicity (data not shown). Thus, it is possible to assume that, with respect to GSH content, neoechinulin A treatment severely disables the cellular GSH antioxidant defense system, indicating that other biological effects imparted by neoechinulin A must compensate for the functional decline. The elevation of the reserve capacity for $\mathrm{NAD}(\mathrm{P}) \mathrm{H}$ redox turnover by neoechinulin A treatment may have contributed to maintaining a proper GSH redox potential $\left([\mathrm{GSH}]^{3)} /[\mathrm{GSSG}]\right.$ ratio), in spite of a significant decrease in the total GSH pool, thereby ameliorating an otherwise weakened GSH antioxidant system. It is clear that a decrease in GSH content and an elevation of the reserve capacity for $\mathrm{NAD}(\mathrm{P}) \mathrm{H}$ turnover is not mechanistically linked. That is, while treatment with neoechinulin A or BSO for $4 \mathrm{~h}$ resulted in a decrease of GSH by $50 \%$ or $30 \%$, respectively, neither treatment affected WST-8 reduction rate at this time point (data not shown). 
It is interesting to note that neoechinulin A has growthinhibitory activity in various tumor cell lines. ${ }^{3)}$ Tumor cells usually have defective mitochondria, which produce more ROS than normal cells. ${ }^{62)}$ However, they also have increased GSH content, which is suggested to contribute to the high proliferation rate and apoptosis-resistant phenotype of the tumor cells. ${ }^{63)}$ The present study implies that perturbation of the GSH redox status through GSH depletion by neoechinulin A may be in part responsible for the antitumor activity of this alkaloid.

\section{CONCLUSION}

Neoechinulin A can also afford cytoprotection against acute NO stress but not against persistent NO stress or oxidative stresses involving entities other than NO. This cytoprotection is associated with an elevation of the cellular reserve capacity for $\mathrm{NAD}(\mathrm{P}) \mathrm{H}$ redox turnover and, paradoxically, a decrease in cellular GSH content. The increased NAD $(\mathrm{P}) \mathrm{H}$ production reserve capacity could compensate for the crippled metabolic systems under nitrosative stress conditions, thereby affording cytoprotection. All of these biological effects of neoechinulin $A$ are unprecedented, and further clarification could have farreaching effects on various biomedical fields including bioenergetics, stress responses, and neurodegeneration.

Acknowledgments This research was partially supported by a Grant-in-Aid for Scientific Research (C) from the Ministry of Education, Culture, Sports, Science and Technology of Japan. The authors dedicate this paper to Mr. Tatsumi Okada, who passed away during the course of this research.

\section{REFERENCES}

1) Deceased.

2) Kimoto K, Aoki T, Shibata Y, Kamisuki S, Sugawara F, Kuramochi K, Nakazaki A, Kobayashi S, Kuroiwa K, Watanabe N, Arai T. Structure-activity relationships of neoechinulin A analogues with cytoprotection against peroxynitrite-induced $\mathrm{PC} 12$ cell death. $J$. Antibiot., 60, 614-621 (2007).

3) Pettit GR, Hogan F, Xu JP, Tan R, Nogawa T, Cichacz Z, Pettit RK, Du J, Ye QH, Cragg GM, Herald CL, Hoard MS, Goswami A, Searcy J, Tackett L, Doubek DL, Williams L, Hooper JN, Schmidt JM, Chapuis JC, Tackett DN, Craciunescu F. Antineoplastic agents. 536. New sources of naturally occurring cancer cell growth inhibitors from marine organisms, terrestrial plants, and microorganisms. J. Nat. Prod., 71, 438-444 (2008).

4) Miller JD, Sun M, Gilyan A, Roy J, Rand TG. Inflammation-associated gene transcription and expression in mouse lungs induced by low molecular weight compounds from fungi from the built environment. Chem. Biol. Interact., 183, 113-124 (2010).

5) Sayre LM, Perry G, Smith MA. Oxidative stress and neurotoxicity. Chem. Res. Toxicol., 21, 172-188 (2008).

6) Knott AB, Bossy-Wetzel E. Nitric oxide in health and disease of the nervous system. Antioxid. Redox Signal., 11, 541-554 (2009).

7) Maruyama K, Ohuchi T, Yoshida K, Shibata Y, Sugawara F, Arai T. Protective properties of neoechinulin A against SIN-1-induced neuronal cell death. J. Biochem., 136, 81-87 (2004).

8) Kuramochi K, Ohnishi K, Fujieda S, Nakajima M, Saitoh Y, Watanabe N, Takeuchi T, Nakazaki A, Sugawara F, Arai T, Kobayashi S. Synthesis and biological activities of neoechinulin A derivatives: new aspects of structure-activity relationships for neoechinulin A. Chem. Pharm. Bull., 56, 1738-1743 (2008).
9) Kajimura Y, Aoki T, Kuramochi K, Kobayashi S, Sugawara F, Watanabe N, Arai T. Neoechinulin A protects PC12 cells against $\mathrm{MPP}^{+}$-induced cytotoxicity. J. Antibiot., 61, 330-333 (2008).

10) Akashi $S$, Kimura T, Takeuchi $T$, Kuramochi K, Kobayashi S, Sugawara $\mathrm{F}$, Watanabe $\mathrm{N}$, Arai $\mathrm{T}$. Neoechinulin a impedes the progression of rotenone-induced cytotoxicity in PC12 cells. Biol. Pharm. Bull., 34, 243-248 (2011).

11) McCord JM, Fridovich I. Superoxide dismutase. An enzymic function for erythrocuprein (hemocuprein). J. Biol. Chem., 244, 60496055 (1969).

12) Carlberg I, Mannervik B. Glutathione reductase. Methods Enzymol., 113, 484-490 (1985).

13) Flohé L, Günzler WA. Assays of glutathione peroxidase. Methods Enzymol., 105, 114-121 (1984).

14) Watanabe N, Dickinson DA, Liu RM, Forman HJ. Quinones and glutathione metabolism. Methods Enzymol., 378, 319-340 (2004).

15) Arnér ES, Zhong L, Holmgren A. Preparation and assay of mammalian thioredoxin and thioredoxin reductase. Methods Enzymol., 300, 226-239 (1999).

16) Mannervik B, Guthenberg C. Glutathione transferase (human placenta). Methods Enzymol., 77, 231-235 (1981).

17) Bateman RL, Rauh D, Tavshanjian B, Shokat KM. Human carbonyl reductase 1 is an $S$-nitrosoglutathione reductase. J. Biol. Chem., 283, 35756-35762 (2008).

18) Ryuman N, Watanabe N, Arai T. $S$-nitrosation of cellular proteins by NO donors in rat embryonic fibroblast $3 \mathrm{Y} 1$ cells: factors affecting S-nitrosation. Oxid. Med. Cell. Longev., 2011, 450317 (2011).

19) Tietze F. Enzymic method for quantitative determination of nanogram amounts of total and oxidized glutathione: applications to mammalian blood and other tissues. Anal. Biochem., 27, 502-522 (1969).

20) Aebi H. Catalase in vitro. Methods Enzymol., 105, 121-126 (1984).

21) Parry DM, Pedersen PL. Intracellular localization and properties of particulate hexokinase in the Novikoff ascites tumor. Evidence for an outer mitochondrial membrane location. J. Biol. Chem., 258, 10904-10912 (1983).

22) Heinz F, Freimuller B. Glyceraldehyde-3-phosphate dehydrogenase from human tissues. Methods Enzymol., 89, Pt D: 301-305 (1982)

23) Matsuoka Y, Srere PA. Kinetic studies of citrate synthase from rat kidney and rat brain. J. Biol. Chem., 248, 8022-8030 (1973).

24) Tian WN, Braunstein LD, Pang J, Stuhlmeier KM, Xi QC, Tian $\mathrm{X}$, Stanton RC. Importance of glucose-6-phosphate dehydrogenase activity for cell growth. J. Biol. Chem., 273, 10609-10617 (1998).

25) Watanabe N, Dickinson DA, Krzywanski DM, Iles KE, Zhang H, Venglarik CJ, Forman HJ. A549 subclones demonstrate heterogeneity in toxicological sensitivity and antioxidant profile. Am. J. Physiol. Lung Cell. Mol. Physiol., 283, L726-L736 (2002).

26) Lee JH, Yang ES, Park JW. Inactivation of $\mathrm{NADP}^{+}$-dependent isocitrate dehydrogenase by peroxynitrite. Implications for cytotoxicity and alcohol-induced liver injury. J. Biol. Chem., 278, 51360-51371 (2003).

27) Wagner TC, Scott MD. Single extraction method for the spectrophotometric quantification of oxidized and reduced pyridine nucleotides in erythrocytes. Anal. Biochem., 222, 417-426 (1994).

28) Biaglow JE, Donahue J, Tuttle S, Held K, Chrestensen C, Mieyal J. A method for measuring disulfide reduction by cultured mammalian cells: relative contributions of glutathione-dependent and glutathione-independent mechanisms. Anal. Biochem., 281, 77-86 (2000).

29) Tominaga $H$, Ishiyama $M$, Ohseto $F$, Sasamoto $K$, Hamamoto $T$, Suzuki K, Watanabe M. K. S, Watanabe M. A water-soluble tetrazolium salt useful for colorimetric cell viability assay. Anal. Commun., 36, 4 (1999).

30) Bindokas VP, Jordán J, Lee CC, Miller RJ. Superoxide production in rat hippocampal neurons: selective imaging with hydroethidine. J. Neurosci., 16, 1324-1336 (1996).

31) Konishi K, Watanabe N, Arai T. SIN-1 cytotoxicity to PC12 cells is 
mediated by thiol-sensitive short-lived substances generated through SIN-1 decomposition in culture medium. Nitric Oxide, 20, 270-278 (2009).

32) Fukuyama S, Kita Y, Hirasawa $Y$, Azuma T, Sato A, Morokoshi N, Koda S, Yasuda T, Oka S, Sakurai H. A new nitric oxide (NO) releaser: spontaneous NO release from FK409. Free Radic. Res., 23, $443-452$ (1995).

33) Keefer LK, Nims RW, Davies KM, Wink DA. "NONOates" (1-substituted diazen-1-ium-1,2-diolates) as nitric oxide donors: convenient nitric oxide dosage forms. Methods Enzymol., 268, 281-293 (1996).

34) Watanabe N, Forman HJ. Autoxidation of extracellular hydroquinones is a causative event for the cytotoxicity of menadione and DMNQ in A549-S cells. Arch. Biochem. Biophys., 411, 145-157 (2003).

35) Liu L, Hausladen A, Zeng M, Que L, Heitman J, Stamler JS. A metabolic enzyme for $S$-nitrosothiol conserved from bacteria to humans. Nature, 410, 490-494 (2001).

36) Haqqani AS, Do SK, Birnboim HC. The role of a formaldehyde dehydrogenase-glutathione pathway in protein $S$-nitrosation in mammalian cells. Nitric Oxide, 9, 172-181 (2003).

37) He J, Wang T, Wang P, Han P, Yin Q, Chen C. A novel mechanism underlying the susceptibility of neuronal cells to nitric oxide: the occurrence and regulation of protein $S$-nitrosylation is the checkpoint. J. Neurochem., 102, 1863-1874 (2007).

38) Kachadourian R, Day BJ. Flavonoid-induced glutathione depletion: potential implications for cancer treatment. Free Radic. Biol. Med., 41, 65-76 (2006).

39) Pullar JM, Hampton MB. Diphenyleneiodonium triggers the efflux of glutathione from cultured cells. J. Biol. Chem., 277, 19402-19407 (2002).

40) Ho HY, Wei TT, Cheng ML, Chiu DT. Green tea polyphenol epigallocatechin-3-gallate protects cells against peroxynitrite-induced cytotoxicity: modulatory effect of cellular G6PD status. J. Agric. Food Chem., 54, 1638-1645 (2006).

41) Clancy RM, Levartovsky D, Leszczynska-Piziak J, Yegudin J, Abramson SB. Nitric oxide reacts with intracellular glutathione and activates the hexose monophosphate shunt in human neutrophils: evidence for $S$-nitrosoglutathione as a bioactive intermediary. Proc. Natl. Acad. Sci. U.S.A., 91, 3680-3684 (1994).

42) Zhang Y, Wang H, Li J, Jimenez DA, Levitan ES, Aizenman E, Rosenberg PA. Peroxynitrite-induced neuronal apoptosis is mediated by intracellular zinc release and 12-lipoxygenase activation. $J$. Neurosci., 24, 10616-10627 (2004).

43) Richardson DR, Lok HC. The nitric oxide-iron interplay in mammalian cells: transport and storage of dinitrosyl iron complexes. Biochim. Biophys. Acta, 1780, 638-651 (2008).

44) Schneider L, Giordano S, Zelickson BR, Johnson SM, Benavides G, Ouyang X, Fineberg N, Darley-Usmar VM, Zhang J. Differentiation of SH-SY5Y cells to a neuronal phenotype changes cellular bioenergetics and the response to oxidative stress. Free Radic. Biol. Med., 51, 2007-2017 (2011).

45) Dawson TM, Bredt DS, Fotuhi M, Hwang PM, Snyder SH. Nitric oxide synthase and neuronal NADPH diaphorase are identical in brain and peripheral tissues. Proc. Natl. Acad. Sci. U.S.A., 88, 7797-7801 (1991).

46) Berridge MV, Herst PM, Tan AS. Tetrazolium dyes as tools in cell biology: new insights into their cellular reduction. Biotechnol. Апnи. Rev., 11, 127-152 (2005).
47) Beltrán B, Orsi A, Clementi E, Moncada S. Oxidative stress and $S$-nitrosylation of proteins in cells. Br. J. Pharmacol., 129, 953-960 (2000).

48) Ramachandran A, Ceaser E, Darley-Usmar VM. Chronic exposure to nitric oxide alters the free iron pool in endothelial cells: role of mitochondrial respiratory complexes and heat shock proteins. Proc. Natl. Acad. Sci. U.S.A., 101, 384-389 (2004).

49) Yasuda M, Fujimori H, Panhou H. NO depletes cellular ATP contents via inactivation of glyceraldehyde-3-phosphate dehydrogenase in PC12 cells. J. Toxicol. Sci., 23, 389-394 (1998).

50) Dimmeler S, Lottspeich F, Brüne B. Nitric oxide causes ADPribosylation and inhibition of glyceraldehyde-3-phosphate dehydrogenase. J. Biol. Chem., 267, 16771-16774 (1992).

51) Yuyama K, Yamamoto H, Nishizaki I, Kato T, Sora I, Yamamoto T. Caspase-independent cell death by low concentrations of nitric oxide in PC12 cells: involvement of cytochrome $c$ oxidase inhibition and the production of reactive oxygen species in mitochondria. $J$. Neurosci. Res., 73, 351-363 (2003).

52) Almeida A, Moncada S, Bolaños JP. Nitric oxide switches on glycolysis through the AMP protein kinase and 6-phosphofructo2-kinase pathway. Nat. Cell Biol., 6, 45-51 (2004).

53) Yasuda M, Uramatsu T, Fujimori H, Pan-Hou H. Correlation between NO-induced ATP depletion and cytotoxicity in PC12 cells. J. Toxicol. Sci., 23, 183-188 (1998).

54) Choi SW, Gerencser AA, Nicholls DG. Bioenergetic analysis of isolated cerebrocortical nerve terminals on a microgram scale: spare respiratory capacity and stochastic mitochondrial failure. J. Neurochem., 109, 1179-1191 (2009).

55) Hill BG, Dranka BP, Zou L, Chatham JC, Darley-Usmar VM. Importance of the bioenergetic reserve capacity in response to cardiomyocyte stress induced by 4-hydroxynonenal. Biochem. J., 424, 99-107 (2009).

56) Dranka BP, Hill BG, Darley-Usmar VM. Mitochondrial reserve capacity in endothelial cells: The impact of nitric oxide and reactive oxygen species. Free Radic. Biol. Med., 48, 905-914 (2010).

57) Sun L, Shukair S, Naik TJ, Moazed F, Ardehali H. Glucose phosphorylation and mitochondrial binding are required for the protective effects of hexokinases I and II. Mol. Cell. Biol., 28, 1007-1017 (2008).

58) Walsh JL, Keith TJ, Knull HR. Glycolytic enzyme interactions with tubulin and microtubules. Biochim. Biophys. Acta, 999, 64-70 (1989).

59) Waingeh VF, Gustafson CD, Kozliak EI, Lowe SL, Knull HR, Thomasson KA. Glycolytic enzyme interactions with yeast and skeletal muscle F-actin. Biophys. J., 90, 1371-1384 (2006).

60) Stanton RC, Seifter JL, Boxer DC, Zimmerman E, Cantley LC. Rapid release of bound glucose-6-phosphate dehydrogenase by growth factors. Correlation with increased enzymatic activity. $J$. Biol. Chem., 266, 12442-12448 (1991).

61) Ibi M, Sawada H, Kume T, Katsuki H, Kaneko S, Shimohama S, Akaike A. Depletion of intracellular glutathione increases susceptibility to nitric oxide in mesencephalic dopaminergic neurons. $J$. Neurochem., 73, 1696-1703 (1999).

62) Brandon M, Baldi P, Wallace DC. Mitochondrial mutations in cancer. Oncogene, 25, 4647-4662 (2006).

63) Ballatori N, Krance SM, Notenboom S, Shi S, Tieu K, Hammond CL. Glutathione dysregulation and the etiology and progression of human diseases. Biol. Chem., 390, 191-214 (2009). 